\title{
Design of Incremental Conductance Sliding Mode MPPT Control Applied by Integrated Photovoltaic and Proton Exchange Membrane Fuel Cell System under Various Operating Conditions for BLDC Motor
}

\author{
Jehun Hahm, ${ }^{1}$ Hyoseok Kang, ${ }^{2}$ Jaeho Baek, ${ }^{3}$ Heejin Lee, ${ }^{4}$ and Mignon Park ${ }^{1}$ \\ ${ }^{1}$ Intelligent Control System Laboratory, Yonsei University, Shin Chon Campus, B2 Building 723, Seoul 120-749, Republic of Korea \\ ${ }^{2}$ MathWorks Korea, LLC, Gangnam-gu, Seoul 135-741, Republic of Korea \\ ${ }^{3}$ Advanced R\&D Team, Samsung Electronics Co., Ltd., Suwon 443-742, Republic of Korea \\ ${ }^{4}$ Hankyong National University, Anseong Campus, S Building 409, Kyonggi-do 456-749, Republic of Korea
}

Correspondence should be addressed to Mignon Park; mignpark@yonsei.ac.kr

Received 23 January 2015; Accepted 29 March 2015

Academic Editor: Mahmoud M. El-Nahass

Copyright (c) 2015 Jehun Hahm et al. This is an open access article distributed under the Creative Commons Attribution License, which permits unrestricted use, distribution, and reproduction in any medium, provided the original work is properly cited.

\begin{abstract}
This paper proposes an integrated photovoltaic (PV) and proton exchange membrane fuel cell (PEMFC) system for continuous energy harvesting under various operating conditions for use with a brushless DC motor. The proposed scheme is based on the incremental conductance (IncCond) algorithm combined with the sliding mode technique. Under changing atmospheric conditions, the energy conversion efficiency of a PV array is very low, leading to significant power losses. Consequently, increasing efficiency by means of maximum power point tracking (MPPT) is particularly important. To manage such a hybrid system, control strategies need to be established to achieve the aim of the distributed system. Firstly, a Matlab/Simulink based model of the PV and PEMFC is developed and validated, as well as the incremental conductance sliding (ICS) MPPT technique; then, different MPPT algorithms are employed to control the PV array under nonuniform temperature and insolation conditions, to study these algorithms effectiveness under various operating conditions. Conventional techniques are easy to implement but produce oscillations at MPP. Compared to these techniques, the proposed technique is more efficient; it produces less oscillation at MPP in the steady state and provides more precise tracking.
\end{abstract}

\section{Introduction}

Recent environmental catastrophes and controversies over the energy source of fossil fuels have elicited vast, active study into energy sources that are clean and cause less environmental contamination. Photovoltaic and fuel cells, consequently, have been widely pursued as renewable energy saving technologies because they do not produce environmental pollution and are abundant and widely available. Renewable energy sources and energy-saving technologies have been studied as ways to solve the problems of the energy crunch and global warming. Among renewable energy technologies, the importance of PV systems and
PEMFCs is gradually increasing because of their benefits of environmental pollution-free operation, low noise, and minimal maintenance requirements. Renewable and new energy technologies are growing rapidly, at an annual average of $40 \%$ over the last decade [1]

To provide alternating current $(\mathrm{AC})$ power from the PV array and the PEMFC to the grid, which is at $220-240 \mathrm{~V}_{\mathrm{rms}}$ in most countries, a power interface is required. PV and PEMFC energy systems have various applications, such as in green household appliances [2,3], in solar cars [4], and in fuel cell cars [5] for remote military missions [6] and even for electric ships and aircrafts $[7,8]$. The BLDC motor is a promising companion technology that has been used extensively in 
many industrial applications owing to its high performance in terms of torque, speed, power factor, efficiency, operation life, control simplicity, and maintainability $[9,10]$.

From the point of view of performance, the output voltage of a PV array can vary greatly under variable weather conditions, which can result in control problems. When weather conditions vary rapidly, it is difficult to keep track of the resulting changes in PV output power [11].

One way to overcome these problems is to employ a PV power generation system hybridized with other power sources such as battery energy storage systems [12], diesel generator systems [13], and fuel cell systems [14]. Battery energy storage systems can be charged or discharged depending on the insolation. Diesel generators are effective backup systems for PV power generation, because they are able to provide continuous power supply throughout the day but have the severe disadvantages that their efficiency is quite poor at low levels of power output and that the use of diesel is counterproductive in addressing the environmental problems of fossil fuels.

As an alternative to diesel generation, fuel cell power systems are very attractive for use with PV systems, because of their benefits including high efficiency, fast load response, modularity, and fuel flexibility. The fast response of the fuel cell is well suited to solve the PV system's inherent problem of intermittent power generation.

PV technology is expected to perform an important function in meeting the growing demand for stand-alone systems at low voltages and also in high power installations, which are usually connected to the grid. If weather conditions, such as ideal insolation and temperature, are good, the PVG system can generate maximum power efficiently. However, nonuniform insolation occurs frequently due to shadowing from sources such as trees, electric poles, neighboring buildings, and clouds.

The renewable energy source flow fluctuates depending on weather conditions, and it must be resolved based on balancing strategy taking into account the difference power value [15-17]. The FC produces as a backup, feeding solely the insufficiency power from the renewable energy based on the load-following strategy. The battery and ultracapacitor hybrid energy storage system produces as a subsidiary source for supplying the power shortage based on dynamic power balance strategy [18]. The load-following control loop is designed to feed the PEMFC system based on average power balancing strategy.

In this paper, it is made up of two main subsystems, the PV system and PEMFC system. In order for PV system to meet the demand completely, there is a need for backup systems. The load is met by the PV system and the PEMFC comes in and discharges when PV output is not sufficient to meet the load.

Many MPPT techniques have been developed. The most widely used algorithms are the Perturb and Observe (P\&O) algorithm and the incremental conductance (IncCond) algorithm $[19,20]$. The $\mathrm{P} \& \mathrm{O}$ algorithm is well known for its simple implementation, but it deviates from and oscillates around the maximum power point (MPP), thereby wasting a considerable amount of the available energy. In addition, the
$\mathrm{P} \& \mathrm{O}$ algorithm can become confused when insolation and temperature atmospheric conditions change rapidly [21]. The IncCond algorithm has good efficiency and accuracy. This algorithm can track the MPP of the PV module by comparing instantaneous conductance with incremental conductance [22]. Therefore, under rapidly changing temperature and insolation atmospheric conditions, it performs well, but its response in finding the MPP is reduced due to the relatively complex computations required by the control algorithm [22-24]. A modified variable-step IncCond MPPT algorithm is based on the conventional IncCond with step-size variation [25]. The step-size variation algorithm is applied to reduce the energy loss on account of the oscillations around the MPP and to enhance the dynamic performance at sudden changes in insolation level.

Herein an incremental conductance sliding (ICS) MPPT technique is proposed for MPPT in nonuniform weather conditions $I-V$ curve characteristic. Sliding mode controllers are well known for their robustness, stability, and advantages for application in nonlinear control systems. Sliding mode controllers are naturally better candidates than conventional MPPT controllers due to their superb robustness and stability properties in handling variable external disturbance. In such external disturbance, the performance of the PV system changes rapidly in response to the changing atmospheric conditions, which typically include nonuniform insolation and temperature due to the movement of the sun and shadows. The output voltage of the PV generation system is unstable during rapidly changing weather conditions. The ICS MPPT algorithm has been proposed to overcome the above problems.

The proposed system combines two renewable energy sources: a PV generation system is used as the system's primary power source, and a PEMFC is utilized as a backup generation system. To evaluate the results of an experiment, the accuracy of the designed proposed MPPT technique and DC-link voltage controller were performed. In addition, a high-power DC-DC converter is needed the DC-link voltage and power of hybrid system to meet the BLDC motor. In this paper, we provide a comprehensive guide to proposed technique. It is our aim to perform these objectives:

(i) demonstrate a more rapid speed for proposed algorithms;

(ii) provide an accurate performance of the oscillating phenomenon;

(iii) propose a flowchart of practicable robust ICS MPPT control for PV system application;

(iv) load-following mode control is implemented by the BLDC motor.

The paper is organized as follows. The theory for the hybrid system and BLDC motor dynamic model is described in Section 2. The system design of the controller is presented in Section 3. Simulation results are compared for the different MPPT techniques in Section 4, with a focus on nonuniform atmospheric conditions. Finally, the MPPT methods are discussed and compared in detail, and conclusions are presented. 


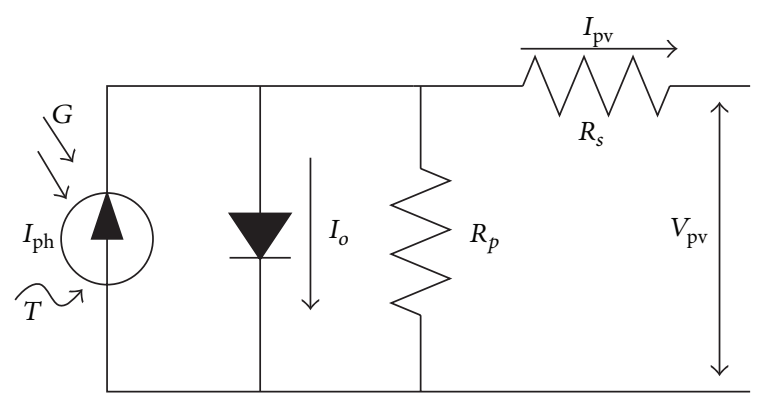

FIGURE 1: Equivalent circuit of a PV cell.

\section{Theory for the Hybrid System and BLDC Motor Dynamic Model}

Based on the work reported in [26-32], the photovoltaic array, the PEMFC, and the BLDC dynamic model are briefly considered in this section.

2.1. PV Array. The PV array consists of a number of cells connected in series or in parallel; Figure 1 shows the equivalent circuit of an ideal PV array. The output and light-induced electromotive current can be written as follows [26-28]:

$$
I_{o}=I_{\mathrm{pv}}-I_{d}-I_{p},
$$

where $I_{o}$ is the PV output current, $I_{\mathrm{pv}}$ is the light-generated current, $I_{d}$ is the diode current, and $I_{p}$ is the parallel resistance current.

Light-generated current is a function of temperature and insolation and is given by

$$
I_{\mathrm{pv}}=I_{\mathrm{scr}} \frac{R}{R_{\mathrm{ref}}}+K_{i}\left(T-T_{\mathrm{ref}}\right),
$$

where $I_{\text {scr }}$ is the cell short-circuit current, $R$ and $R_{\text {ref }}$ are the input insolation and reference insolation, respectively, and $T$ and $T_{\text {ref }}$ are the cell temperature and the reference temperature in Kelvin, respectively. $K_{i}$ is the short-circuit current temperature coefficient.

Then, the diode current, which is a function of the saturation current, can be written as

$$
I_{d}=I_{\text {sat }}\left\{\exp ^{q\left(V_{o}+I_{o} R_{s}\right) / A k T}-1\right\},
$$

where $I_{\text {sat }}$ is the diode saturation current, $R_{s}$ is the series resistance, $k$ is the Boltzmann constant $\left[1.3805 \times 10^{-23} \mathrm{~N} \cdot \mathrm{m} / \mathrm{K}\right]$, and $q$ is the electron charge $\left[1.6021 \times 10^{-19} \mathrm{C}\right]$.

Furthermore, the parallel resistance current gives a measure of the PV cell loss; it can be calculated as follows:

$$
I_{p}=\left(\frac{V_{o}+I_{o} R_{s}}{R_{p}}\right)
$$

where $R_{p}$ is the parallel resistance.

Finally, the saturation current varies as a function of temperature and can be expressed as

$$
I_{\text {sat }}=I_{\text {satr }}\left(\frac{T}{T_{\text {ref }}}\right)^{3} \exp ^{\left\{\left(q E_{g} / B k\right)\left(\left(1 / T_{R}\right)-\left(1 / T_{\mathrm{C}}\right)\right)\right\}},
$$

where $I_{\text {satr }}$ is the reference cell saturation current, $T_{\text {ref }}$ is the ideality factor, and $E_{g}$ is the cell band gap energy.

With reference to Figure 2, the PV voltage characteristics are nonlinear in response to changes in solar insolation and temperature. Figure 2(a) shows characteristic $I-V$ curves of a PV array for various values of constant insolation; as the isolation increases, the open-circuit voltage and short-circuit current of the PV cell both increase. Similarly, Figure 2(b) depicts characteristic $I-V$ curves of a PV array for various constant temperatures. Note that as the temperature increases, the characteristic short-circuit current increases slightly and the open-circuit voltage decreases. Four cases of partially shaded PV modules were also investigated, as reported in Figure 2(c). Under full insolation, the $I-V$ characteristic had one peak; however, when partial shading of the PV modules occurred, multiple peaks existed.

2.2. PEMFC. The characteristic operation of the PEMFC can be understood by using the relation between the voltage and current of the fuel cell stack, the internal current density, and each loss component.

A typical $I-V$ plot for a PEMFC is shown in Figure 3. Note that, during operation, the PEMFC's actual voltage is less than its theoretical voltage [31] because the electrochemical response is met with internal resistance, which is an irreversible phenomenon. The drop in the open-circuit voltage caused by drawing electric current is known as polarization.

As noted in Figure 3, there are three kinds of polarization in a PEMFC: activation polarization, ohmic polarization, and concentrate polarization. The resulting voltage can be expressed as follows [29-32]:

$$
E=N_{0}\left(E_{0}+\frac{R T}{2 F} \ln \left(\frac{P_{\mathrm{H}_{2}} \sqrt{P_{\mathrm{O}_{2}}}}{P_{\mathrm{H}_{2} \mathrm{O}}}\right)\right)-L,
$$

where $E, N_{0}, E_{0}$, and $L$ represent the output stack voltage, the number of cells in the stack, the open-circuit cell voltage, and the voltage losses, respectively. In addition, $R, T$, and $F$ denote the universal gas constant, the operating temperature, and Faraday's constant [ $96485 \mathrm{C} / \mathrm{mole}$ ]. Also, $P_{\mathrm{H}_{2}}, P_{\mathrm{O}_{2}}$, and $P_{\mathrm{H}_{2} \mathrm{O}}$ represent the partial pressures of hydrogen, oxygen, and water, respectively.

The ohmic polarization voltage area decreases as the resistance polarization area increases, primarily owing to internal resistance $[29,32]$. Consequently, the characteristic output follows Ohm's law and becomes like a voltage of losses, which can be written as follows [32]:

$$
L=\underbrace{\left(i+i_{n}\right) r}_{\Delta V_{\mathrm{ohm}}}+\underbrace{a \ln \left(\frac{i+i_{n}}{i_{o}}\right)}_{\Delta V_{\mathrm{act}}}-\underbrace{b \ln \left(1-\frac{i+i_{n}}{i_{l}}\right)}_{\Delta V_{\text {con }}},
$$

where $i, i_{n}, i_{o}$, and $i_{l}$ denote the output, internal, exchange, and limiting current densities, respectively. Additionally, $a$ and $b$ are the constants of activation losses (i.e., the slope of the Tafel line) and concentration, respectively. 

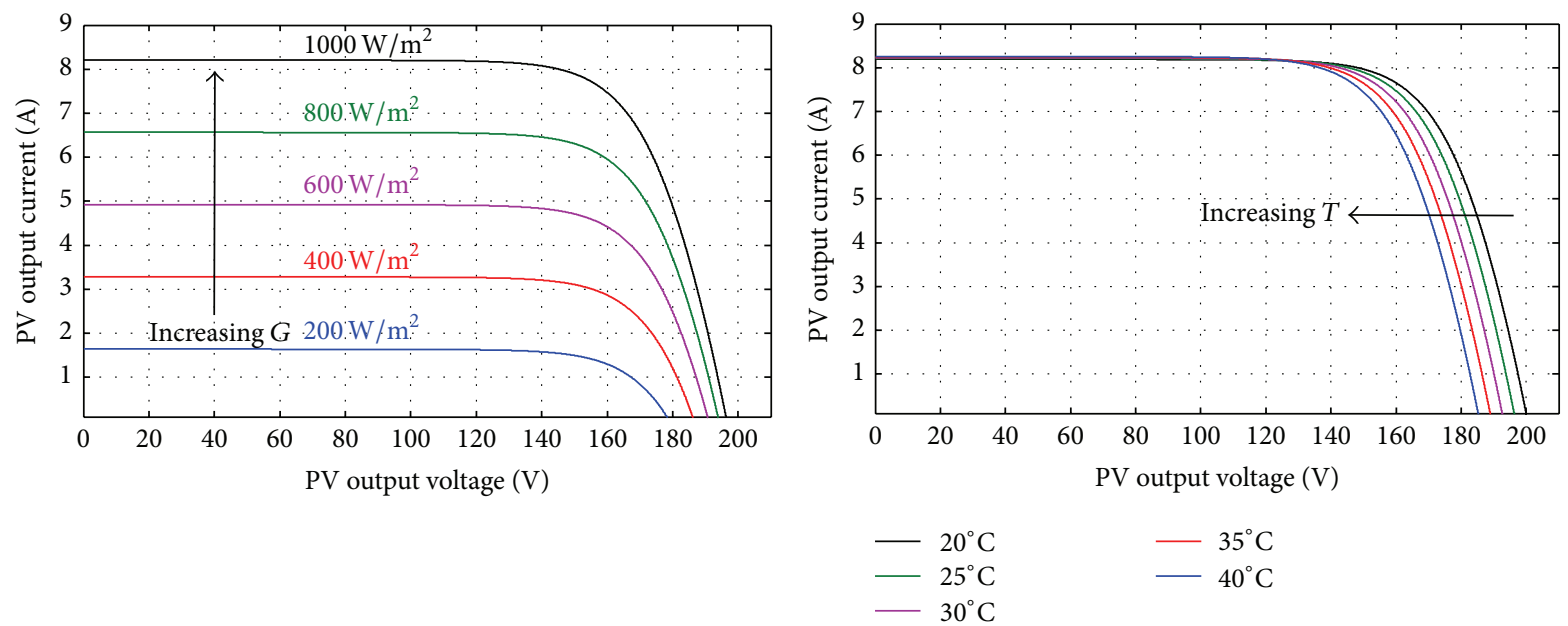

(a)

(b)

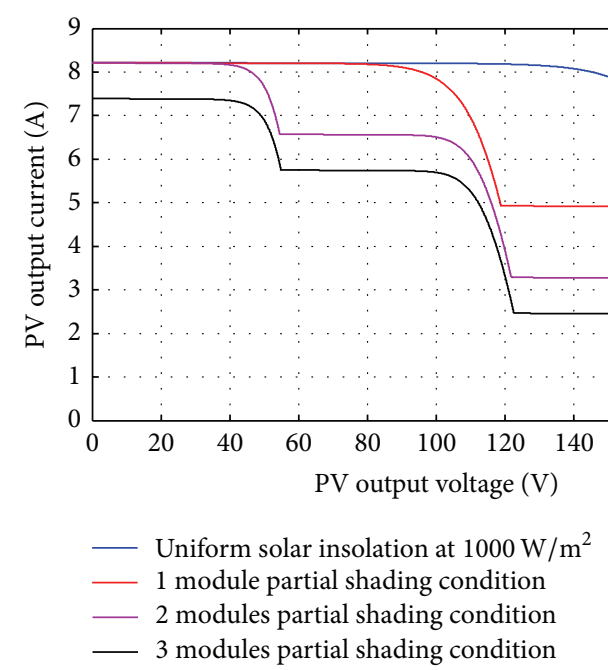

(c)

FIGURE 2: Influence upon $I-V$ characteristics of (a) constant uniform insolation conditions $(G)$; (b) constant uniform temperature conditions $(T)$; and (c) various shading conditions.

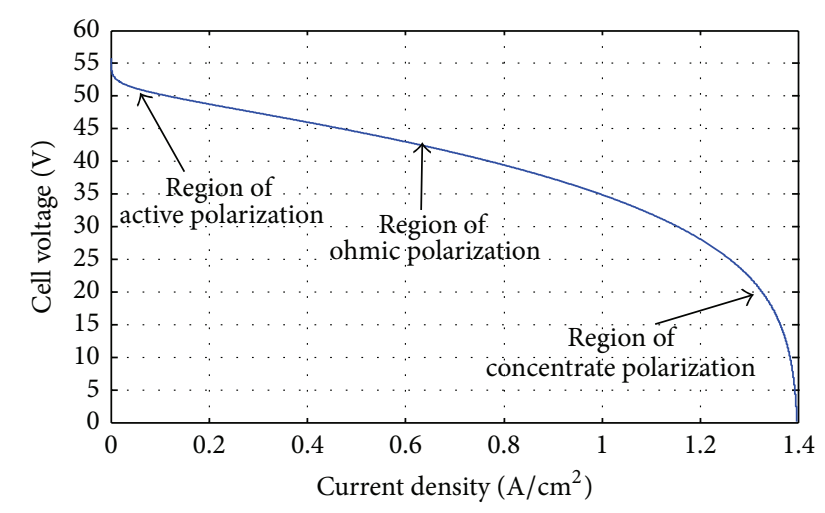

FIgURE 3: $I-V$ characteristic of a PEMFC.

2.3. Brushless DC (BLDC) Motor. The equations used to model the BLDC motor comprise a voltage equation, a torque equation, and a motion equation [33]. In general, the stator of a BLDC motor has three windings, like that of an induction motor or a permanent magnet synchronous motor. The voltage equations of the three-winding model can be written as follows $[34,35]$ :

$$
\begin{aligned}
{\left[\begin{array}{l}
v_{a n} \\
v_{b n} \\
v_{c n}
\end{array}\right]=} & {\left[\begin{array}{lll}
R & 0 & 0 \\
0 & R & 0 \\
0 & 0 & 0
\end{array}\right]\left[\begin{array}{l}
i_{a} \\
i_{b} \\
i_{c}
\end{array}\right] } \\
& \cdot\left[\begin{array}{ccc}
L-M & 0 & 0 \\
0 & L-M & 0 \\
0 & 0 & L-M
\end{array}\right]\left[\begin{array}{c}
i_{a} \\
\dot{i}_{b} \\
\dot{i}_{c}
\end{array}\right]+\left[\begin{array}{c}
e_{a} \\
e_{b} \\
e_{c}
\end{array}\right], \\
v_{a n}= & \frac{1}{3}\left(\sum_{i=a}^{c} v_{i}-\sum_{i=a}^{c} e_{i}\right),
\end{aligned}
$$




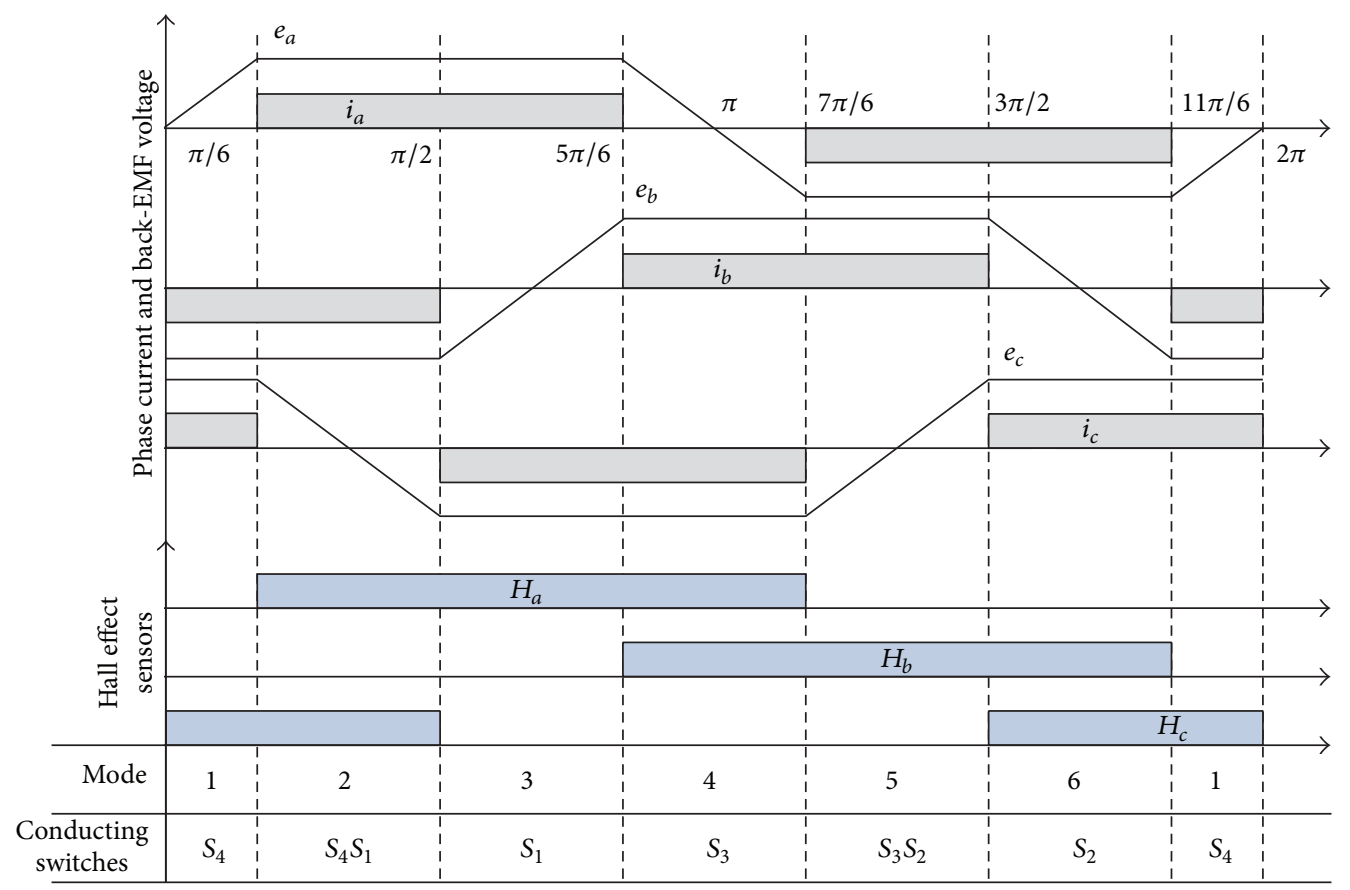

Figure 4: Phase current and back-EMF voltage.

where $v_{a n}, e_{a n}$, and $i_{a n}$ are the terminal voltage, the back-EMF voltage, and the current phase $n$, respectively. $L$ and $M$ are the stator winding self-inductance and the mutual inductance of each phase. Next, the torque of a BLDC motor can be given by

$$
\tau_{d}=\frac{1}{\omega_{r}}\left(e_{a} i_{a}+e_{b} i_{b}+e_{c} i_{c}\right),
$$

where $\tau_{d}$ is the electromagnetic torque and $\omega_{r}$ is the motor speed.

Thus, the motion equation is

$$
\dot{\omega}=\frac{\tau_{d}-\tau_{l}-B \omega_{r}}{J},
$$

where $J$ is the motor inertia, $B$ is the damping ratio, and $\tau_{l}$ is the load torque.

Figure 4 shows the trapezoid back-EMF voltage and the waveform of the phase current for a three-phase BLDC motor [34]. In addition, the six-switch inverter generation of $120^{\circ}$ leading current waveforms is naturally difficult for the reason that there are limited voltage vectors [35].

\section{Design of the Controller System}

3.1. Control Design Strategy. We design the control strategy of the overall system, which was developed and implemented using Matlab/Simulink, which is shown in Figure 5(a). Within this paper and taking into consideration the effects of changes in insolation and temperature on the PV system under a shaded module, four MPPT methods that build on the $\mathrm{P} \& \mathrm{O}$, IncCond, modified variable-step IncCond algorithms, and the proposed controller are implemented, evaluated, and compared in a Matlab/Simulink environment. Most traditional MPPT algorithms converge to a local maximum, which is not the global maximum output point on the P-V curve. This results in a considerable decrease in PV system, in addition to the efficiency of the MPPT algorithm. To resolve this problem, partially shaded PV modules can be implemented using an incremental conductance sliding (ICS) MPPT technique.

3.2. Phase-Shift Full-Bridge Converter. The DC-DC converter uses a phase-shift full-bridge (PSFB) converter for the fuel cell system. A PSFB converter performs zero-voltage switching by charging and discharging the MOSFET parasitic capacitor using leakage inductance from the transformer [36].

Figure 5(a) gives a block diagram for the overall control of the proposed system. Power is supplied from the photovoltaic cell to the boost converter and from the fuel cell stack to the PSFB converter, the outputs of which are connected in parallel to a DC-AC inverter. For adequate current control, both these converters can be modeled as constant-current sources emanating from the inverter and connected in parallel.

3.3. Boost Converter. The PV module configuration used in this simulation study to test nonuniform atmospheric conditions is illustrated schematically in Figure 5(b). The feasibility design of a PV array and a PEMFC parallel operation, two different kinds of DC-DC converters, are designed for DC-link voltage stability. The PEMFC terminal voltage is calculated based on the desired PEMFC power by using a voltage controller and a current controller. The configuration of the control topology of the two individual DC-DC converters was shown in Figures 6(a) and 6(b). 


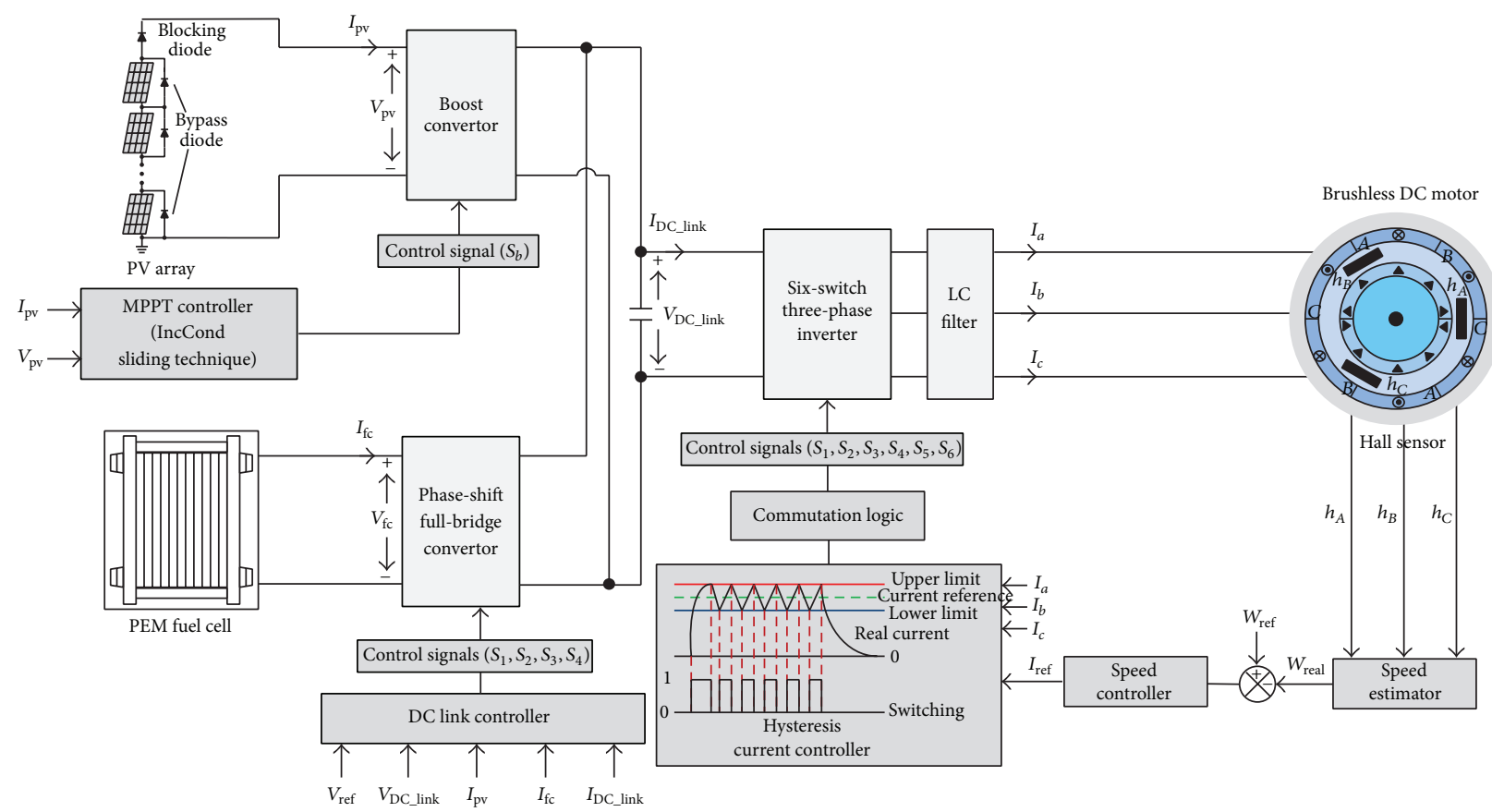

(a)

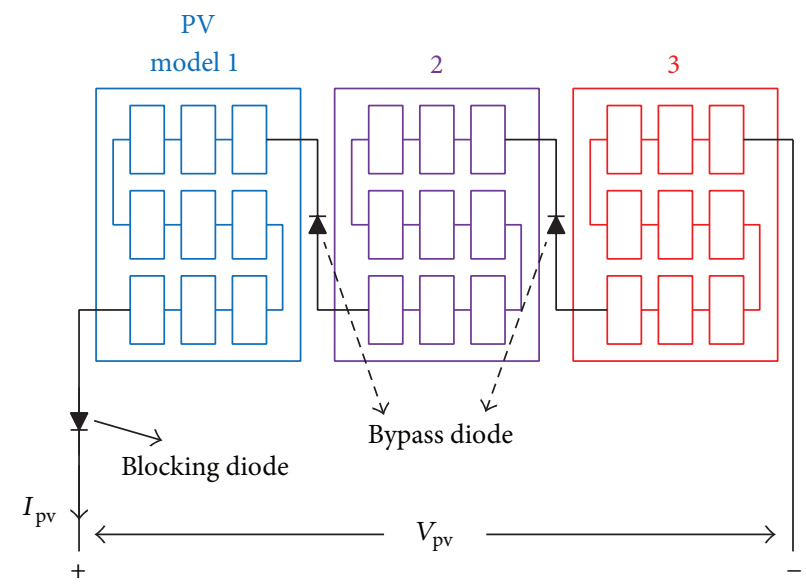

(b)

FIGURE 5: Simplified schematic of the PV-PEMFC system configuration: (a) block diagram of the proposed hybrid system configuration implementing MPPT by means of the proposed ICS technique and (b) PV array configuration used in this simulation study under atmospheric conditions.

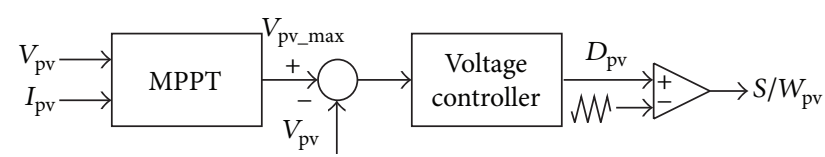

(a)

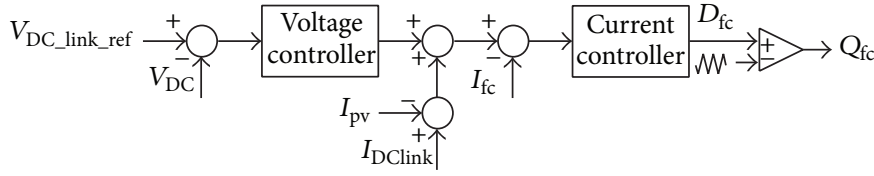

(b)

FIGURE 6: Control topology for DC-DC converters: (a) block scheme of the MPPT technique used to control the PV system and (b) block scheme of the DC-link control for the PEMFC system. 


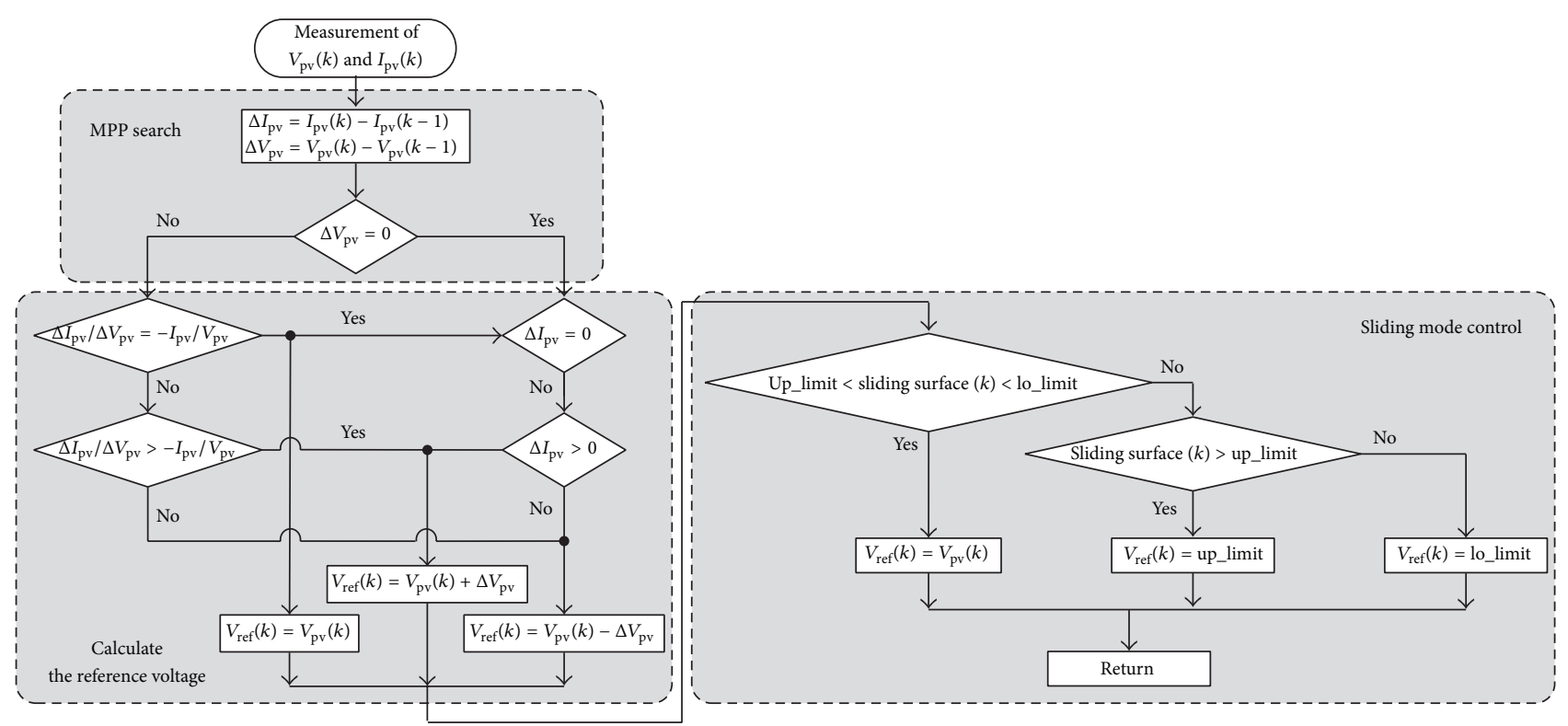

(a)

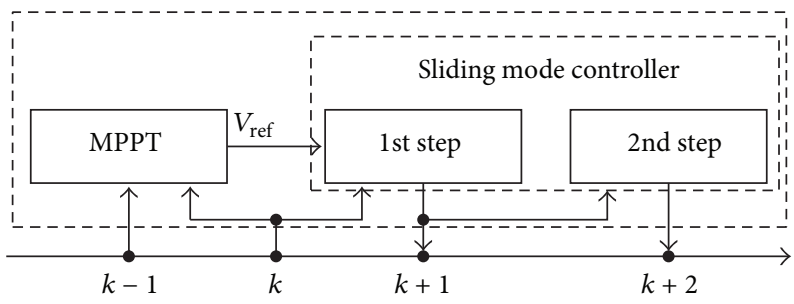

(b)

FIGURE 7: Flowchart of the proposed MPPT technique: (a) block scheme of IncCond sliding mode control algorithm imposing the reference voltage $V_{\text {ref }}$ on the controller and (b) sampling instant of the process between the MPPT and the sliding mode controller.

First, we designed the boost converter to raise its output voltage. The state equations of the boost converter can be given as follows $[37,38]$ :

$$
\left[\begin{array}{l}
\frac{d i_{L}}{d t} \\
\frac{d V_{o}}{d t}
\end{array}\right]=\left[\begin{array}{cc}
0 & \frac{-(1-S)}{L} \\
\frac{1-S}{C} & \frac{-1}{R C}
\end{array}\right]\left[\begin{array}{c}
i_{L} \\
V_{o}
\end{array}\right]+\left[\begin{array}{c}
\frac{1}{L} \\
0
\end{array}\right] V_{i},
$$

where the switching signal $(S)$ takes the value 1 or $0, V_{i}$ is the energy source of the boost converter, and $V_{o}$ is the DC-link voltage.

The terminal voltage of the PV system is controlled by the voltage error signal. The PV voltage is controlled to determine the reference DC-link voltage at which the MPPT occurs. The MPPT controller is required to make the system a closed-loop control system wherein the error signal, which is the difference between the actual and the reference DClink voltage of the PV array, is fed to the voltage controller to control the duty cycle of the boost converter. The total supply voltage must be controlled to meet the load demand requirements, for the reason that the output voltage of the $\mathrm{PV}$ generator fluctuates along with the irradiation. The PEMFC output voltage can be adjusted by the difference voltage command $\Delta V$, which is the DC-link voltage of the command value $V_{\mathrm{DC}}$ minus the sum of the voltage generated by the PV $\operatorname{array}\left(V_{\mathrm{PV}}\right)$ :

$$
V_{\mathrm{FC}}=\Delta V=V_{\mathrm{DC}}-V_{\mathrm{PV}} .
$$

Power is supplied from each PV array to the boost converter and from each fuel cell stack to the PSFB converter, which is then connected to a DC-AC inverter in series.

This characteristic DC-AC inverter is supported by the proposed system and the 3-phase BLDC motor. The inverter governs both the velocity and the hysteresis current control while a PI controller regulates the current and the DC-link output voltage, which is set at $400 \mathrm{~V}$.

\subsection{Incremental Conductance Sliding (ICS) MPPT Control.} The photovoltaic output voltage is basically a function of atmospheric factors such as temperature and insolation. The incremental conductance (IncCond) algorithm is the most commonly used method because its results can be computed quickly and its control is easily implemented [24, 39, 40]; however, this method is characterized by overshoot and oscillation when the MPP is reached.

Figure 7(a) illustrates the scheme of the proposed ICS technique; in the figure, the time $k-1$ corresponds to the 
previous cycle time of $t-1$, whereas $k$ represents the real-time calculations for the present cycle. MPP tracking is carried out by differentiating the PV system output power $\left(P_{\mathrm{pv}}\right)$ with respect to voltage $\left(V_{\mathrm{pv}}\right)$ and setting it to be equal to zero to determine the desired operating point, as follows:

$$
\begin{aligned}
\frac{d P_{\mathrm{pv}}}{d V_{\mathrm{pv}}} & =\frac{d\left(V_{\mathrm{pv}} \cdot I_{\mathrm{pv}}\right)}{d V_{\mathrm{pv}}} \\
& =I_{\mathrm{pv}}+V_{\mathrm{pv}} \frac{d I_{\mathrm{pv}}}{d V_{\mathrm{pv}}} \cong I_{\mathrm{pv}}+V_{\mathrm{pv}} \frac{\Delta I_{\mathrm{pv}}}{\Delta V_{\mathrm{pv}}} \\
& \Longrightarrow \begin{cases}\frac{\Delta P_{\mathrm{pv}}}{\Delta V_{\mathrm{pv}}}>0 & \text { if } \frac{I_{\mathrm{pv}}}{V_{\mathrm{pv}}}>-\frac{\Delta I_{\mathrm{pv}}}{\Delta V_{\mathrm{pv}}}, \text { left of MPP } \\
\frac{\Delta P_{\mathrm{pv}}}{\Delta V_{\mathrm{pv}}}=0 & \text { if } \frac{I_{\mathrm{pv}}}{V_{\mathrm{pv}}}=-\frac{\Delta I_{\mathrm{pv}}}{\Delta V_{\mathrm{pv}}}, \text { at MPP } \\
\frac{\Delta P_{\mathrm{pv}}}{\Delta V_{\mathrm{pv}}}<0 & \text { if } \frac{I_{\mathrm{pv}}}{V_{\mathrm{pv}}}<-\frac{\Delta I_{\mathrm{pv}}}{\Delta V_{\mathrm{pv}}}, \text { right of MPP. }\end{cases}
\end{aligned}
$$

The MPP can be tracked by comparing the instantaneous $\left(I_{\mathrm{pv}} / V_{\mathrm{pv}}\right)$ to the incremental conductance $\left(\Delta I_{\mathrm{pv}} / \Delta V_{\mathrm{pv}}\right)$, as shown in Figure $7(\mathrm{a}) . V_{\text {ref }}$ is the control signal voltage used to adjust the operating point of the PV array to reach the voltage corresponding to the MPP. Once the MPP voltage is reached, the $\mathrm{PV}$ array is kept at this operating point unless an alteration in $\Delta I_{\mathrm{pv}}$ is noted, indicating an alteration in the weather conditions and the MPP. The algorithm decrements or increments $V_{\text {ref }}$ to track the new MPP. To implement sliding mode control (SMC), we use a saturation function; Up_limit is the upper limit and Lo_limit is the lower limit of the saturation function. When the sliding surface is between the lower saturation limit and the upper saturation limit, the output is $V_{\text {ref. }}$. Otherwise, the output is one of these two limits.

The proposed control method for the two-step SMC is presented in Figure $7(\mathrm{~b})$. At time $k$, the MPPT compares the values obtained for the previous cycle time $k-1$ with the measured ones keeping the present values and, simultaneously, yields and imposes the particular reference voltage to the SMC. The second inputs the reference voltage and the measured value forcing the PV array to operate with the desirable voltage at time $k-2$.

3.5. BLDC Motor Control. Generally used in AC motors and power supplies, PWM inverters are current-controlled. In particular, hysteresis band current control methods are frequently utilized for current-controlled applications in electronic circuit systems [41].

The notable characteristics of hysteresis band current control strategies include their excellent dynamic response, low cost, and easy implementation. In addition, they have very high response speed and high accuracy [41, 42]. However, they also have a variable switching frequency, as well as large current ripples that manifest when trying to achieve a steady state [41].

A normal hysteresis band current control for the regulation of a power filter line current is shown in Figure 8(a); note
TABLE 1: System simulation parameters.

\begin{tabular}{lcc}
\hline & PEMFC & PV system \\
\hline Input voltage & $25-50 \mathrm{~V}$ & $140-200 \mathrm{~V}$ \\
DC-link voltage & $400 \mathrm{~V}$ & $400 \mathrm{~V}$ \\
DC-link capacitor & $470 \mu \mathrm{F}$ & $470 \mu \mathrm{F}$ \\
Switching frequency & $50 \mathrm{kHz}$ & $20 \mathrm{kHz}$ \\
\hline
\end{tabular}

that the hysteresis is organized around a reference current $[43,44]$.

The reference current of the power filter is given by $i_{a \text {,ref, }}$, whereas the actual current of the power filter is given by $i_{a}$.

The current error can be written as follows [45]:

$$
i_{e}=i-i_{\text {ref }}
$$

The error of each phase current is controlled by a twolevel hysteresis comparator, which is shown in Figure 8(b).

The hysteresis band current controller functions as a power filter; its switching logic is defined as follows.

If $i_{a}<\left(i_{a, \text { ref }}-e_{\text {min }}\right)$, then the upper switch is OFF and the lower switch is ON for leg " $a$ ".

If $i_{a}<\left(i_{a, \text { ref }}+e_{\max }\right)$, then the upper switch is $\mathrm{ON}$ and the lower switch is OFF for leg " $a$ ”.

Switching logic is necessary because the three phases are coupled. Then, the output is a PWM signal in a 6-switch inverter.

\section{Results and Discussion}

To study the dynamic behavior of the typical PV system, four MPPT algorithms based on P\&O, on IncCond, on modified variable-step IncCond, and on the proposed controller were implemented, evaluated, and compared in a Matlab/Simulink environment, taking into consideration the changes in insolation and temperature experienced by the PV system when there is a partially shaded module. There are different possibilities for the insolation and temperature among the PV array elements; the following three cases were randomly considered. The simulation results for the three cases suggest that a partially shaded module causes a reduction in PV output power. PV output power characteristics for all cases are depicted in Figure 9. Table 1 lists the model parameters used.

(i) Case 1 (Test under Nonuniform Climatic Conditions in PV Module 1; Constant Climatic Conditions in Modules 2 and 3). Figures 10(a) and 10(b) show isolation and temperature variations from partial shading; PV module 1 was simulated to experience these nonuniform conditions (with insolation $G 1$ varying from 600 to $1000 \mathrm{~W} / \mathrm{m}^{2}$ and temperature $T 1$ varying from 20 to $35^{\circ} \mathrm{C}$ ), while PV modules 2 and 3 experienced two different sets of constant climatic conditions (PV module 2: $800 \mathrm{~W} / \mathrm{m}^{2}, 25^{\circ} \mathrm{C}$, and PV module 3: $500 \mathrm{~W} / \mathrm{m}^{2}, 40^{\circ} \mathrm{C}$ ). The dynamic response of the PV system comprising these three modules was controlled by using four techniques, as illustrated in Figures 10(c) and 10(d).

With reference to Figures $10(\mathrm{c})$ and $10(\mathrm{~d})$, we observe that the response curves obtained by the proposed method, 


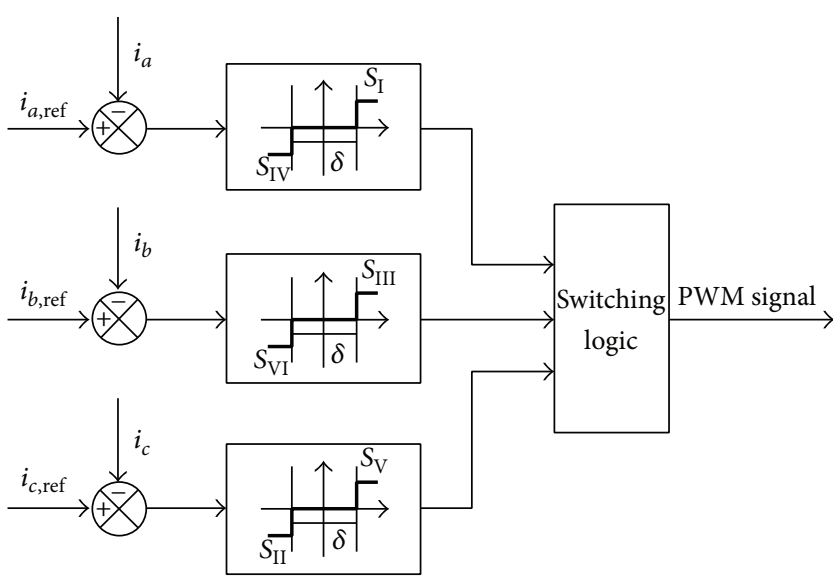

(a)

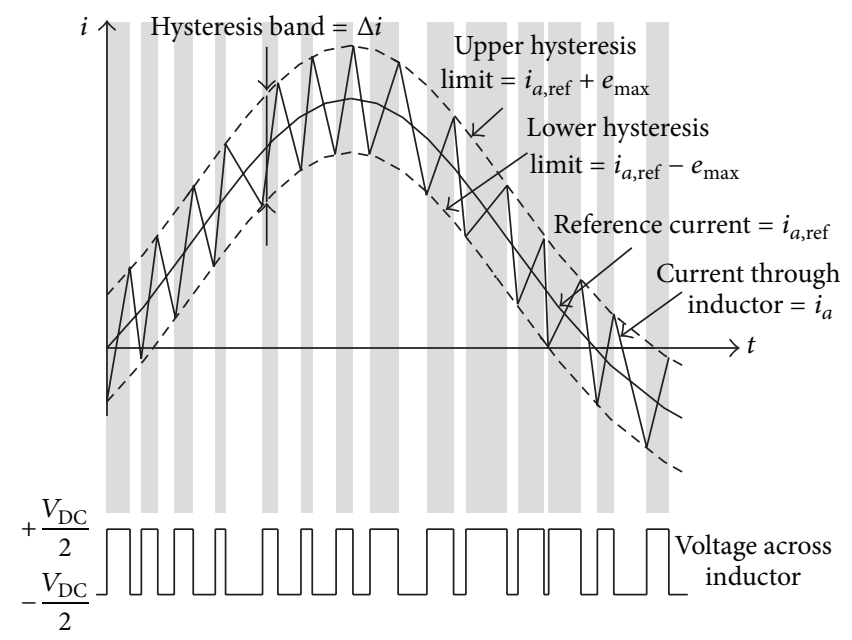

(b)

FIGURE 8: Hysteresis band current controller at phase " $a$ ": (a) structure of hysteresis band current control and (b) hysteresis band current control of the current and voltage wave.

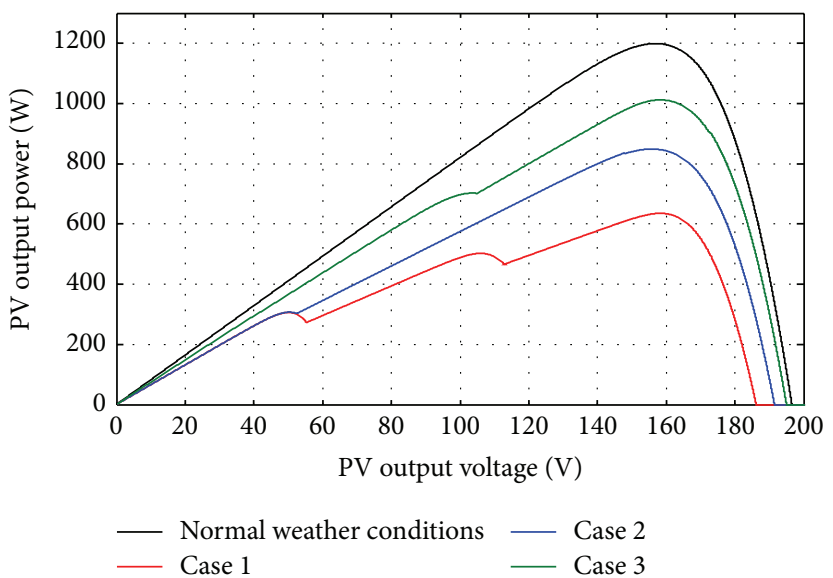

FIGURE 9: PV output power characteristics under different partial shade conditions (three cases).

most remarkably the voltage and power curves, responded more quickly and without much oscillation, relative to two conventional methods and modified variable-step IncCond technique. The $\mathrm{P} \& \mathrm{O}$ technique caused some voltage loss because its use can cause the PV system to oscillate around the maximum power point. The modified variable-step IncCond technique had more precise control and less, stable oscillation than the two conventional techniques. However, the proposed technique had the most accurate control and the least oscillation in steady-state operation among the control methods tested.

(ii) Case 2 (Test under Nonuniform Climatic Conditions in PV Modules 1 and 2; Constant Climatic Conditions in Module 3). In this case, the insolation and temperature levels simulated for PV module 3 represent shading (PV module $3: 700 \mathrm{~W} / \mathrm{m}^{2}$, $25^{\circ} \mathrm{C}$ ), and the other modules experience nonuniform atmospheric conditions (PV module 1: insolation $G 1$ varying from 600 to $800 \mathrm{~W} / \mathrm{m}^{2}$ and temperature $T 1$ varying from 22 to $30^{\circ} \mathrm{C}$; PV module 2: insolation $G 2$ varying from 700 to $850 \mathrm{~W} / \mathrm{m}^{2}$ and temperature $\mathrm{T} 3$ varying from 25 to $44^{\circ} \mathrm{C}$ ) as shown in Figures 11(a) and 11(b). Figures 11(c) and 11(d) show the dynamic response of the PV system under control by the four methods tested.

By referring to Figures 11(c) and 11(d), the proposed method responded the most quickly and stably among the four methods. The conventional method and modified variable-step IncCond technique had greater oscillations and responded more slowly than the proposed method.

(iii) Case 3 (Test under Nonuniform Climatic Conditions in All PV Modules). We were interested in testing the scenario in which all PV modules experience nonuniform insolation and temperature. We report in Figures 12(a) and 12(b) that varying climatic conditions were simulated for each of the PV modules, including random insolation from 724 to $947 \mathrm{~W} / \mathrm{m}^{2}$ and temperature from 22 to $32^{\circ} \mathrm{C}$; the proposed control technique clearly responded the most quickly and performed 


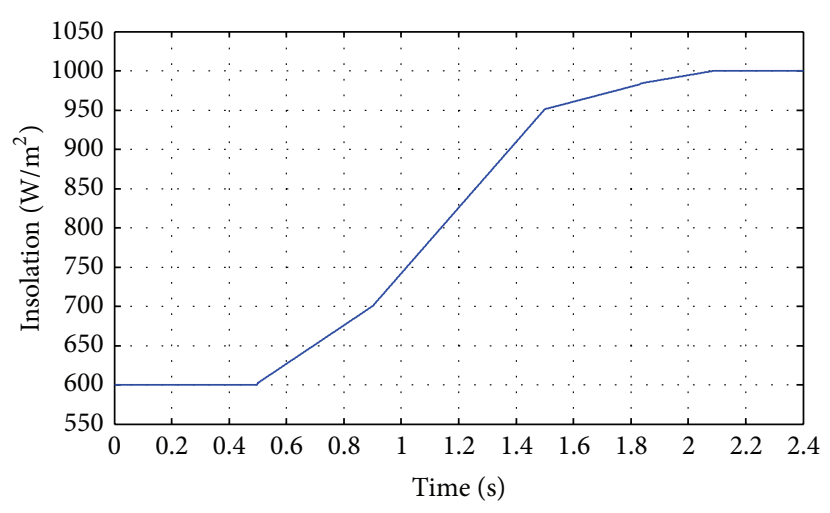

— Insolation variation $(G 1)$

(a)

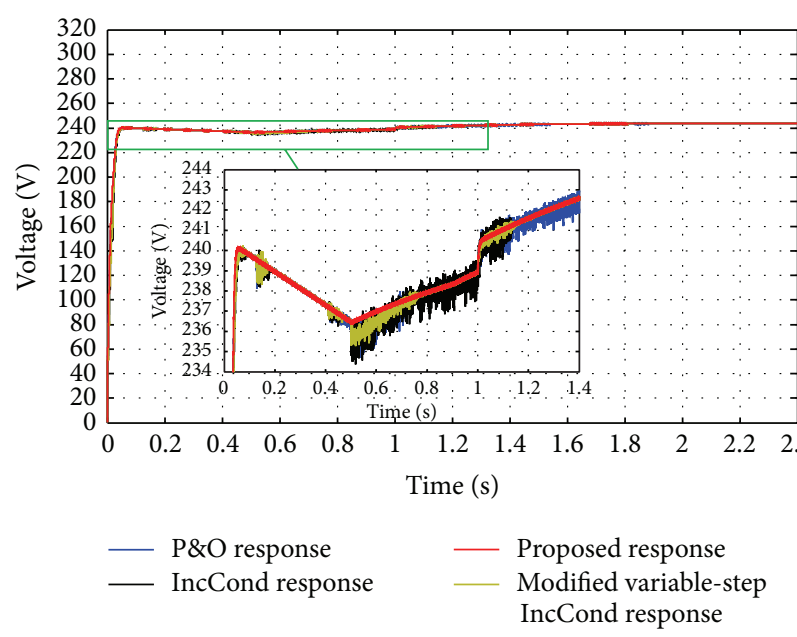

(c)

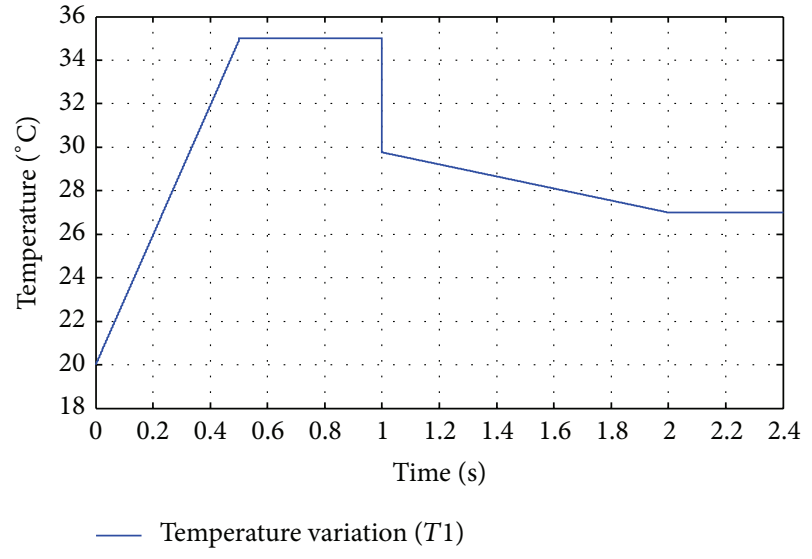

(b)

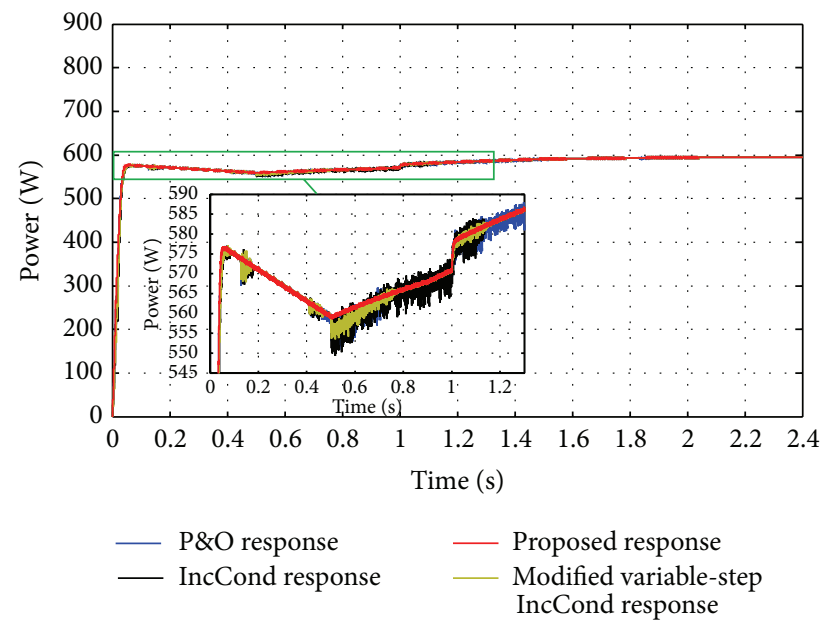

(d)

FIGURE 10: Influence of insolation and temperature variations: (a) insolation variation (G1); (b) temperature variation (T1); (c) PV voltage response to the variations under three control schemes; and (d) PV power response to the variations under four control schemes.

the most stably, as shown in Figures 12(c) and 12(d). The technique developed was tested for a resistive load, connected to a DC-DC converter. However, we additionally tested the proposed method as well as our algorithm for use with BLDC motor loads to demonstrate their performance. In this experiment, the DC-link voltage of the hybrid system stabilized at $400 \mathrm{~V}$ after $0.08 \mathrm{~s}$, as shown in Figure 12(e). The DC-link voltage of the hybrid system overshot slightly, and then the phase current of the BLDC motor was stabilized; the phase current of the 3-phase BLDC motor stabilized at the reference current (5 A) after $0.2 \mathrm{~s}$, as shown in Figure 12(f). Figure $12(\mathrm{~g})$ shows hysteresis current control of the BLDC motor; the lower and upper band current values were 5 and $6 \mathrm{~A}$, respectively. The reference and real speeds of BLDC motor are illustrated in Figure 12(h).

\section{Conclusions}

The performance of different MPPT methods used in the PV system was critically assessed under nonuniform atmospheric conditions. The performance of the proposed ICS control technique was compared with that of conventional MPPT methods and modified variable-step IncCond MPPT method under varying solar insolation and temperature conditions corresponding to cloudy weather. Simulation results were performed, showing that the conventional MPPT techniques and modified variable-step IncCond MPPT performed reasonably well under nonuniform atmospheric conditions. However, the use of these techniques tends to cause oscillations of the PV array operating point at MPP under rapidly changing conditions of partial shading and temperature. The modified variable-step IncCond MPPT algorithm performed more efficiently in response to rapidly changing atmospheric conditions and was more stable during MPP tracking, compared with the two conventional algorithms.

Tables 2, 3, and 4 show comparative assessment of four MPPT techniques. The performance is accessed in terms of energy produced by PV array, the oscillation in power at time $t=0.5 \mathrm{sec}$, and the response times to achieve the MPP. From the Tables 2, 3, and 4 results, the proposed MPPT technique works quite well whereas their performance degrades as compared to other MPPT algorithms. The 


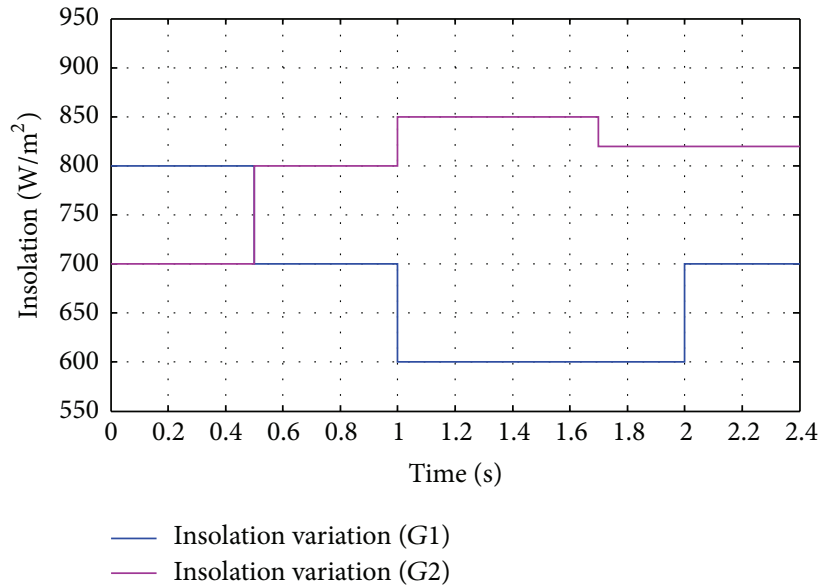

(a)

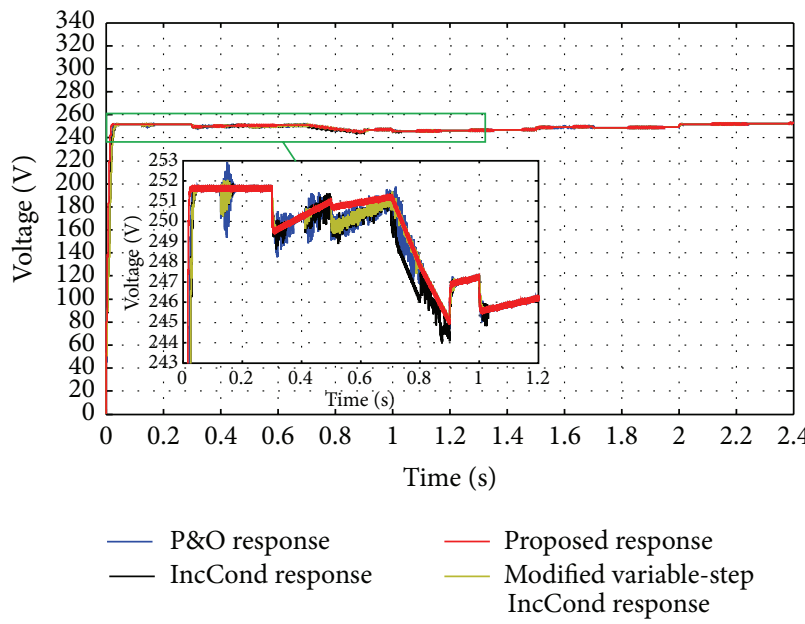

(c)

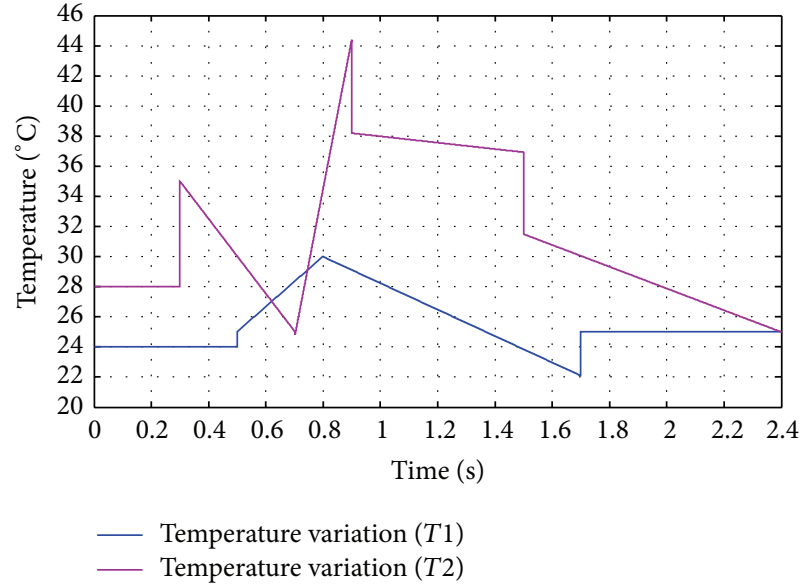

(b)

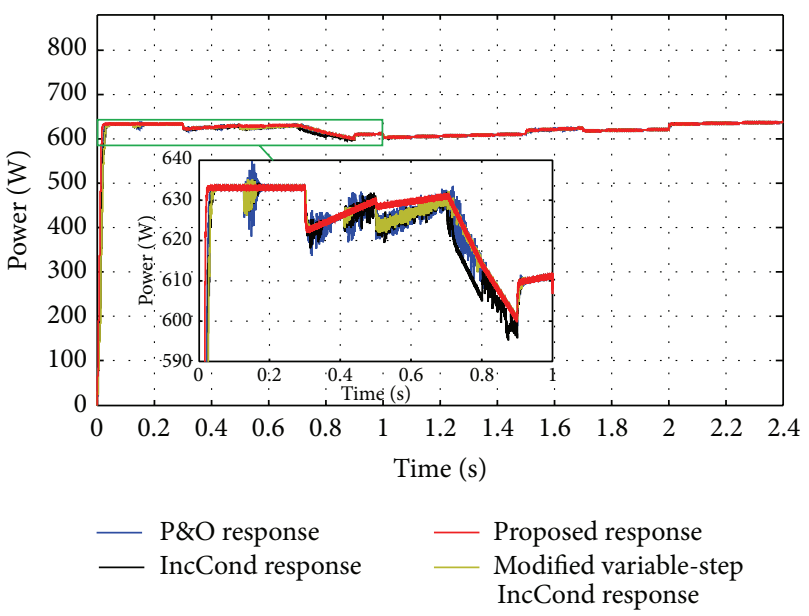

(d)

FIGURE 11: Influence of insolation and temperature variations: (a) insolation variation (G1, G2); (b) temperature variation (T1, T2); (c) PV voltage response to the variations under three control schemes; and (d) PV power response to the variations under four control schemes.

TABLE 2: Comparative assessment of different MPPT algorithms at Case 1.

\begin{tabular}{lcc}
\hline Algorithms & $\begin{array}{c}\text { Oscillation around } \\
\text { MPP (W) }\end{array}$ & $\begin{array}{c}\text { Response } \\
\text { time }(\mathrm{s})\end{array}$ \\
\hline Perturb and Observe & 6.8 & 0.064 \\
IncCond & 8.4 & 0.094 \\
Modified variable-step IncCond & 6.1 & 0.094 \\
Proposed ICS & 0.9 & 0.051 \\
\hline
\end{tabular}

proposed method worked well under varying conditions of nonuniform insolation and temperature, with less oscillation and faster response. The efficiency of the proposed scheme in such conditions was demonstrated by means of simulations. The proposed method provided more stable operation, greater reliability and feasibility, and faster response than two conventional MPPT techniques and modified variablestep IncCond MPPT. The main advantages of the technique
TABLE 3: Comparative assessment of different MPPT algorithms at Case 2.

\begin{tabular}{lcc}
\hline Algorithms & $\begin{array}{c}\text { Oscillation } \\
\text { around MPP (W) }\end{array}$ & $\begin{array}{c}\text { Response } \\
\text { time (s) }\end{array}$ \\
\hline Perturb and Observe & 10.2 & 0.032 \\
IncCond & 8.9 & 0.046 \\
Modified variable-step IncCond & 7.9 & 0.044 \\
Proposed ICS & 1.4 & 0.021 \\
\hline
\end{tabular}

developed herein are its fast convergence to the MPP, its robustness, its higher efficiency, and the possibility of easy implementation.

\section{Conflict of Interests}

The authors declare that there is no conflict of interests regarding the publication of this paper. 


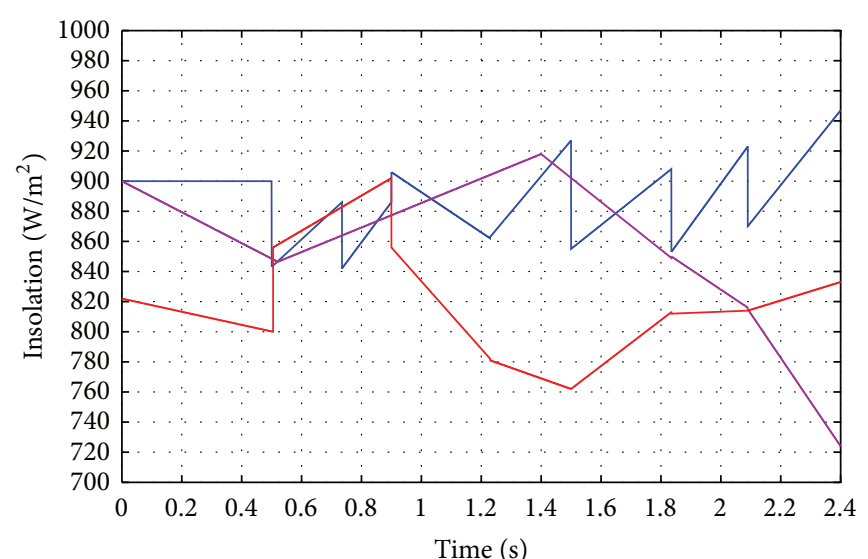

_ Insolation variation $(G 1)$

— Insolation variation $(G 2)$

— Insolation variation (G3)

(a)

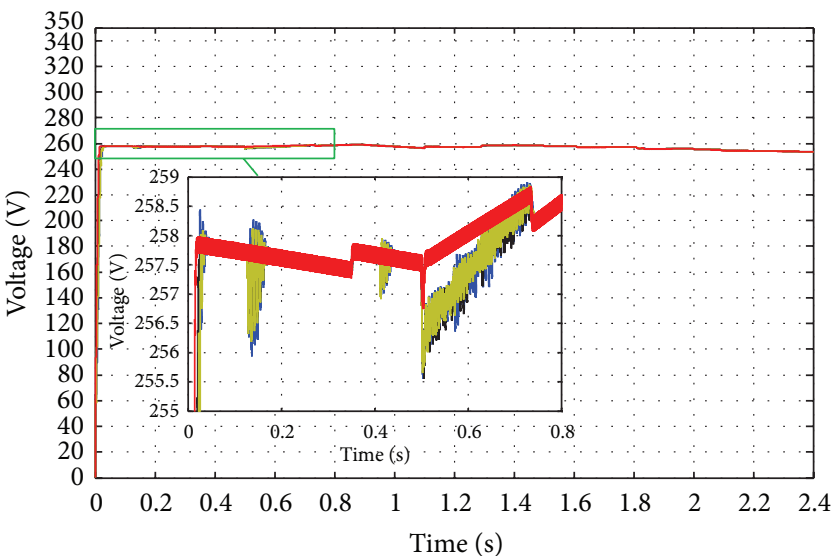

- P\&O response

— IncCond response

Modified variable-step IncCond response

- Proposed response

(c)

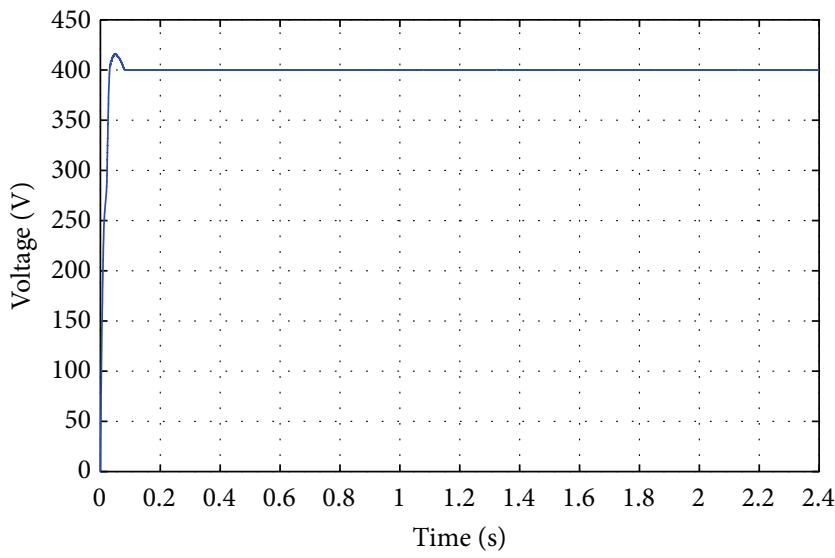

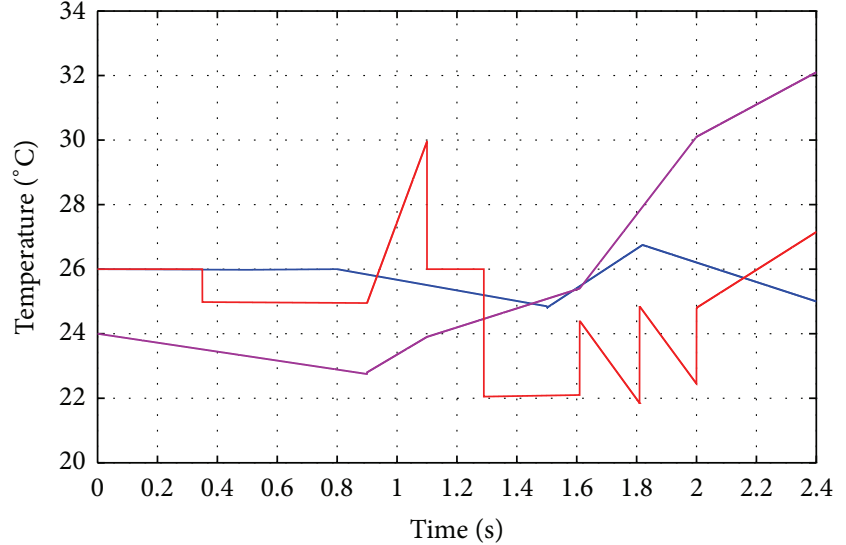

_ Temperature variation (T1)

— Temperature variation (T2)

— Temperature variation (T3)

(b)

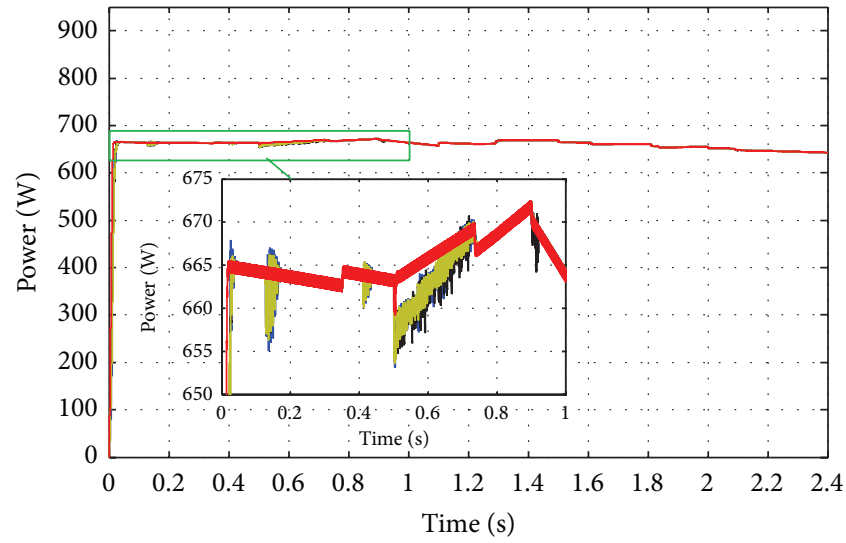

$\mathrm{P} \& \mathrm{O}$ response

IncCond response

Modified variable-step IncCond response

Proposed response

(d)

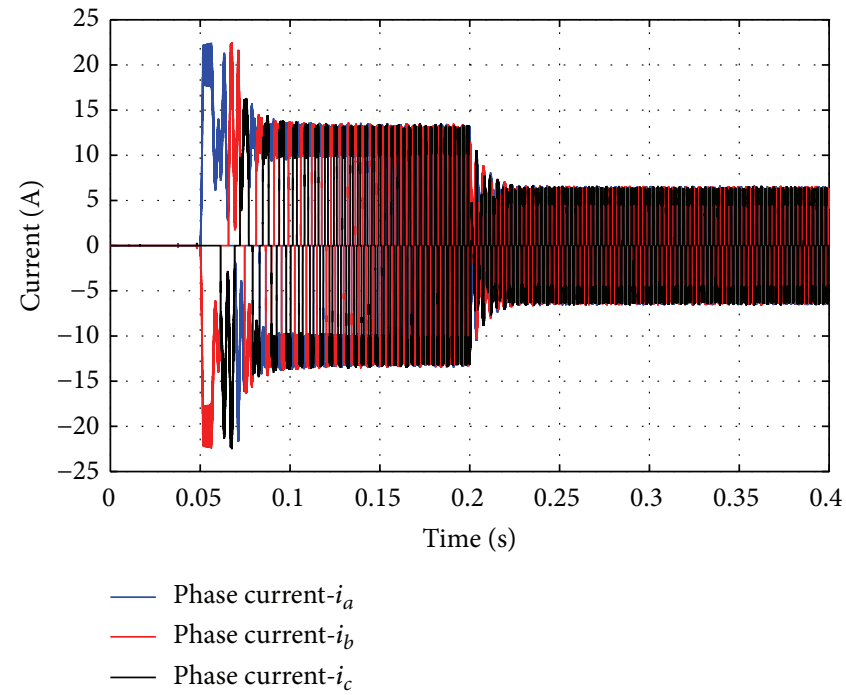

(f)

(e)

Figure 12: Continued. 


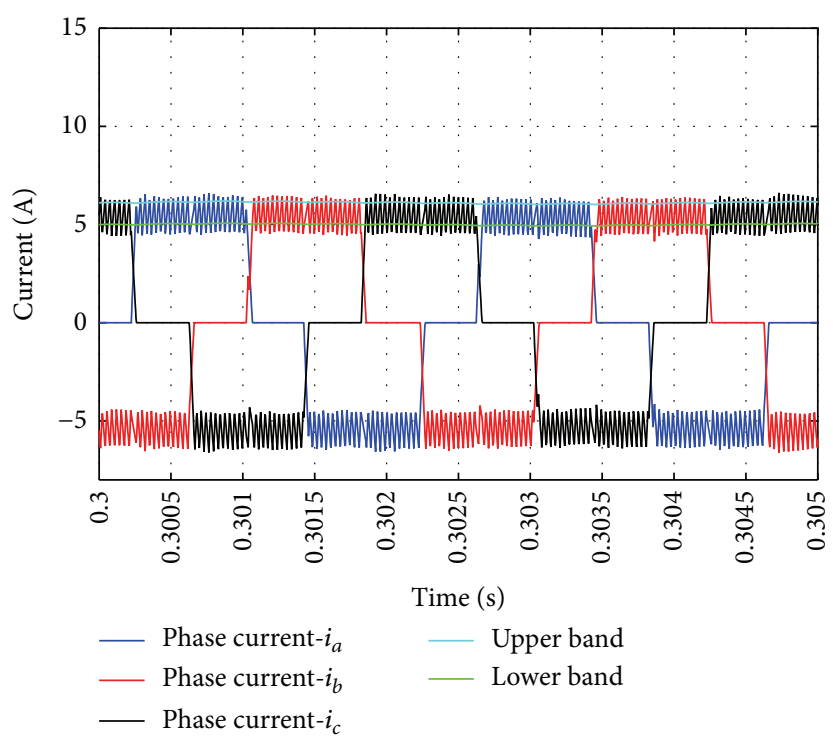

(g)

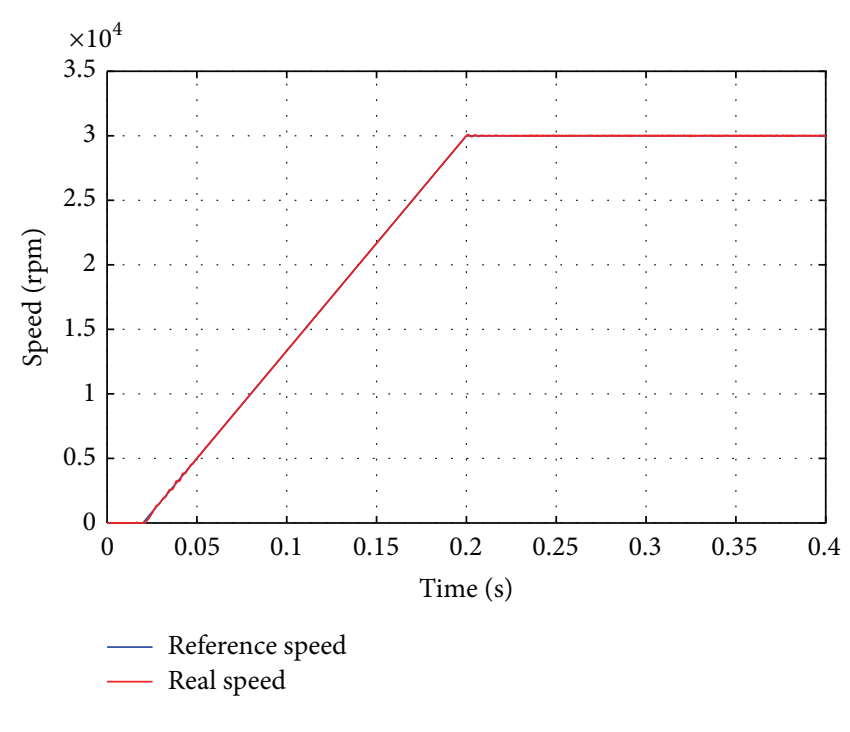

(h)

FIGURE 12: Influence of insolation and temperature variations: (a) insolation variation (G1, G2, and G3); (b) temperature variation (T1, T2, and T3); (c) PV voltage response to the variations under three control schemes; (d) PV power response to the variations under four control schemes; (e) DC-link voltage of hybrid system; (f) phase current of the BLDC motor; (g) hysteresis current control of the BLDC motor; and (h) reference and real speeds of the BLDC motor.

TABLE 4: Comparative assessment of different MPPT algorithms at Case 3 .

\begin{tabular}{lcc}
\hline Algorithms & $\begin{array}{c}\text { Oscillation around } \\
\text { MPP }(\mathrm{W})\end{array}$ & $\begin{array}{c}\text { Response } \\
\text { time }(\mathrm{s})\end{array}$ \\
\hline Perturb and Observe & 10.8 & 0.053 \\
IncCond & 10.3 & 0.467 \\
Modified variable-step IncCond & 10.3 & 0.475 \\
Proposed ICS & 4.7 & 0.021 \\
\hline
\end{tabular}

\section{References}

[1] P. Frankl and S. Nowak, Technology Roadmap: Solar Photovoltaic Energy, OECD/IEA, 2010.

[2] J. O. Jaber, Q. M. Jaber, S. A. Sawalha, and M. S. Mohsen, "Evaluation of conventional and renewable energy sources for space heating in the household sector," Renewable and Sustainable Energy Reviews, vol. 12, no. 1, pp. 278-289, 2008.

[3] W. C. Lattin and V. P. Utgikar, "Transition to hydrogen economy in the United States: a 2006 status report," International Journal of Hydrogen Energy, vol. 32, no. 15, pp. 3230-3237, 2007.

[4] G. Rizzo, I. Arsie, and M. Sorrentino, "Solar energy for cars: perspectives, opportunities and problems," in Proceedings of the GTAA Meeting, pp. 1-6, Mulhouse, France, May 2010.

[5] D. K. Ross, "Hydrogen storage: the major technological barrier to the development of hydrogen fuel cell cars," Vacuum, vol. 80, no. 10, pp. 1084-1089, 2006.

[6] S. M. Diamond and M. G. Ceruti, "Application of wireless sensor network to military information integration," in Proceedings of the 5th IEEE International Conference on Industrial Informatics (INDIN '07), pp. 316-322, Vienna, Austria, June 2007.
[7] B. C. Mecrow and A. G. Jack, "Efficiency trends in electric machines and drives," Energy Policy, vol. 36, no. 12, pp. 43364341, 2008.

[8] R. A. Smith, "Enabling technologies for demand management: transport," Energy Policy, vol. 36, no. 12, pp. 4444-4448, 2008.

[9] W. Hong, W. Lee, and B.-K. Lee, "Dynamic simulation of brushless DC motor drives considering phase commutation for automotive applications," in Proceedings of the IEEE International Electric Machines and Drives Conference (IEMDC '07), pp. 1377-1383, Antalya, Turkey, May 2007.

[10] P. Pillay and R. Krishnan, "Modeling, simulation, and analysis of permanent-magnet motor drives. II. The brushless DC motor drive," IEEE Transactions on Industry Applications, vol. 25, no. 2, pp. 274-279, 1989.

[11] X. Sun, W. Wu, B. Wang, and X. Wei, "A research on photovoltaic energy controlling system," in Proceedings of the 5th International Conference on Electrical Machines and Systems (ICEMS '01), vol. 1, pp. 542-545, Shenyang, China, August 2001.

[12] S. J. Chiang, K. T. Chang, and C. Y. Yen, "Residential photovoltaic energy storage system," IEEE Transactions on Industrial Electronics, vol. 45, no. 3, pp. 385-394, 1998.

[13] R. Dufo-López and J. L. Bernal-Agustín, "Design and control strategies of PV-diesel systems using genetic algorithms," Solar Energy, vol. 79, no. 1, pp. 33-46, 2005.

[14] M. Hatti, A. Meharrar, and M. Tioursi, "Power management strategy in the alternative energy photovoltaic/PEM Fuel Cell hybrid system," Renewable and Sustainable Energy Reviews, vol. 15, no. 9, pp. 5104-5110, 2011.

[15] Y. Zhu and K. Tomsovic, "Development of models for analyzing the load-following performance of microturbines and fuel cells," Electric Power Systems Research, vol. 62, no. 1, pp. 1-11, 2002. 
[16] N. Bizon, "Load-following mode control of a standalone renewable/fuel cell hybrid power source," Energy Conversion and Management, vol. 77, pp. 763-772, 2014.

[17] K. Sopian, A. Zaharim, Y. Ali, Z. M. Nopiah, J. A. B. Razak, and N. S. Muhammad, "Optimal operational strategy for hybrid renewable energy system using genetic algorithms," WSEAS Transactions on Mathematics, vol. 7, no. 4, pp. 130-140, 2008.

[18] H. Fakham, D. Lu, and B. Francois, "Power control design of a battery charger in a hybrid active PV generator for load-following applications," IEEE Transactions on Industrial Electronics, vol. 58, no. 1, pp. 85-94, 2011.

[19] M. Calais and H. Hinz, "A ripple-based maximum power point tracking algorithm for a single-phase, grid-connected photovoltaic system," Solar Energy, vol. 63, no. 5, pp. 277-282, 1998.

[20] D. Sera, T. Kerekes, R. Teodorescu, and F. Blaabjerg, "Improved MPPT method for rapidly changing environmental conditions," in Proceedings of the International Symposium on Industrial Electronics (ISIE '06), pp. 1420-1425, Montreal, Canada, July 2006.

[21] C. W. Tan, T. C. Green, and C. A. Hernandez-Aramburo, "An improved maximum power point tracking algorithm with current-mode control for photovoltaic applications," in Proceedings of the International Conference on Power Electronics and Drives Systems (PEDS '05), vol. 1, pp. 489-494, IEEE, Kuala Lumpur, Malaysia, November 2005.

[22] T. Esram and P. L. Chapman, "Comparison of photovoltaic array maximum power point tracking techniques," IEEE Transactions on Energy Conversion, vol. 22, no. 2, pp. 439-449, 2007.

[23] E. Koutroulis, K. Kalaitzakis, and N. C. Voulgaris, "Development of a microcontroller-based, photovoltaic maximum power point tracking control system," IEEE Transactions on Power Electronics, vol. 16, no. 1, pp. 46-54, 2001.

[24] A. Zegaoui, M. Aillerie, P. Petit, J. P. Sawicki, J. P. Charles, and A. W. Belarbi, "Dynamic behaviour of PV generator trackers under irradiation and temperature changes," Solar Energy, vol. 85, no. 11, pp. 2953-2964, 2011.

[25] N. E. Zakzouk, A. K. Abdelsalam, A. A. Helal, and B. W. Williams, "Modified variable-step incremental conductance maximum power point tracking technique for photovoltaic systems," in Proceedings of the 39th Annual Conference of the IEEE Industrial Electronics Society (IECON '13), pp. 1741-1748, IEEE, Vienna, Austria, November 2013.

[26] W. Xiao, W. G. Dunford, and A. Capel, "A novel modeling method for photovoltaic cells," in Proceedings of the IEEE 35th Annual Power Electronics Specialists Conference (PESC '04), pp. 1950-1956, IEEE, June 2004.

[27] J. A. Gow and C. D. Manning, "Development of a photovoltaic array model for use in power-electronics simulation studies," IEE Proceedings_Electric Power Applications, vol. 146, no. 2, pp. 193-200, 1999.

[28] W. De Soto, S. A. Klein, and W. A. Beckman, "Improvement and validation of a model for photovoltaic array performance," Solar Energy, vol. 80, no. 1, pp. 78-88, 2006.

[29] L.-Y. Chiu, B. Diong, and R. S. Gemmen, "An improved smallsignal model of the dynamic behavior of PEM fuel cells," IEEE Transactions on Industry Applications, vol. 40, no. 4, pp. 970977, 2004.

[30] Q. Li, W. Chen, Y. Wang, J. Jia, and M. Han, "Nonlinear robust control of proton exchange membrane fuel cell by state feedback exact linearization," Journal of Power Sources, vol. 194, no. 1, pp. 338-348, 2009.
[31] C. J. Hatziadoniu, A. A. Lobo, F. Pourboghrat, and M. Daneshdoost, "A simplified dynamic model of grid-connected fuel-cell generators," IEEE Transactions on Power Delivery, vol. 17, no. 2, pp. 467-473, 2002.

[32] J. Larminie, A. Dicks, and M. S. McDonald, Fuel Cell Systems Explained, Wiley, New York, NY, USA, 2003.

[33] C. Cai, H. Zhang, J. Liu, and Y. Gao, "Modeling and simulation of BLDC motor in electric power steering," in Proceedings of the Asia-Pacific Power and Energy Engineering Conference (APPEEC '10), pp. 1-4, Chengdu, China, March 2010.

[34] B. K. Lee and M. Ehsani, "Advanced BLDC motor drive for low cost and high performance propulsion system in electric and hybrid vehicles," in Proceedings of the IEEE International Electric Machines and Drives Conference (IEMDC '01), pp. 246251, Cambridge, Mass, USA, June 2001.

[35] B.-K. Lee, T.-H. Kim, and M. Ehsani, "On the feasibility of fourswitch three-phase BLDC motor drives for low cost commercial applications: topology and control," IEEE Transactions on Power Electronics, vol. 18, no. 1 I, pp. 164-172, 2003.

[36] H. Bai, Z. Nie, and C. C. Mi, "Experimental comparison of traditional phase-shift, dual-phase-shift, and model-based control of isolated bidirectional Dc-Dc converters," IEEE Transactions on Power Electronics, vol. 25, no. 6, pp. 1444-1449, 2010.

[37] D. Das, R. Esmaili, L. Xu, and D. Nichols, "An optimal design of a grid connected hybrid wind/photovoltaic/fuel cell system for distributed energy production," in Proceedings of the 31st Annual Conference of IEEE Industrial Electronics Society (IECON '05), pp. 2499-2504, November 2005.

[38] T. Monai, I. Takano, H. Nishikawa, and Y. Sawada, "Response characteristics and operating methods of new type dispersed power supply system using photovoltaic fuel cell and SMES," in Proceedings of the IEEE Power Engineering Society Summer Meeting, vol. 2, pp. 874-879, IEEE, Chicago, Ill, USA, June 2002.

[39] V. Salas, E. Olías, A. Barrado, and A. Lázaro, "Review of the maximum power point tracking algorithms for stand-alone photovoltaic systems," Solar Energy Materials and Solar Cells, vol. 90, no. 11, pp. 1555-1578, 2006.

[40] K. Ishaque and Z. Salam, "A review of maximum power point tracking techniques of PV system for uniform insolation and partial shading condition," Renewable and Sustainable Energy Reviews, vol. 19, pp. 475-488, 2013.

[41] A. N. Jog and N. G. Apte, "An adaptive hysteresis band current controlled shunt active power filter," in Proceedings of the 5th International Conference-Workshop Compatibility in Power Electronics (CPE '07), pp. 1-5, Gdansk, Poland, May-June 2007.

[42] J. Holtz, "Pulsewidth modulation-a survey," IEEE Transactions on Industrial Electronics, vol. 39, no. 5, pp. 410-420, 1992.

[43] G. Vázquez, P. Rodriguez, R. Ordoñez, T. Kerekes, and R. Teodorescu, "Adaptive hysteresis band current control for transformerless single-phase PV inverters," in Proceedings of the 35th Annual Conference of IEEE Industrial Electronics (IECON '09), pp. 173-177, IEEE, Porto, Portugal, November 2009.

[44] B. K. Bose, "An adaptive hysteresis-band current control technique of a voltage-fed PWM inverter for machine drive system," IEEE Transactions on Industrial Electronics, vol. 37, no. 5, pp. 402-408, 1990.

[45] L. Dalessandro, U. Drofenik, S. D. Round, and J. W. Kolar, "A novel hysteresis current control for three-phase three-level PWM rectifiers," in Proceedings of the 20th Annual IEEE Applied Power Electronics Conference and Exposition (APEC '05), vol. 1, pp. 501-507, IEEE, March 2005. 

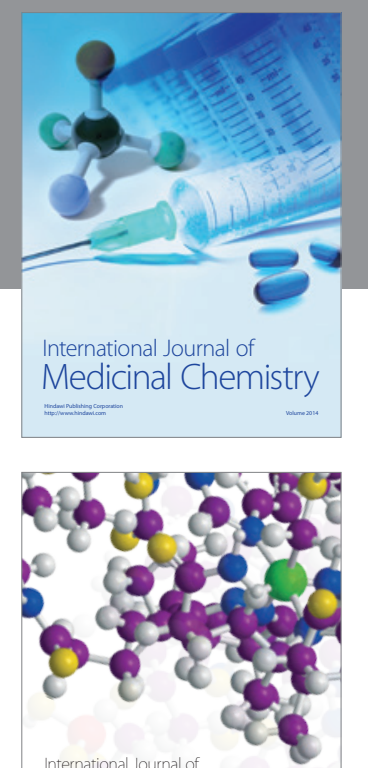

\section{Carbohydrate} Chemistry

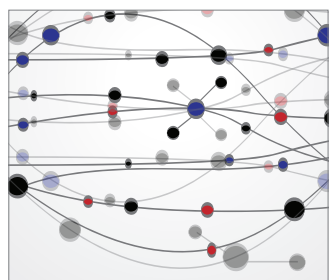

The Scientific World Journal
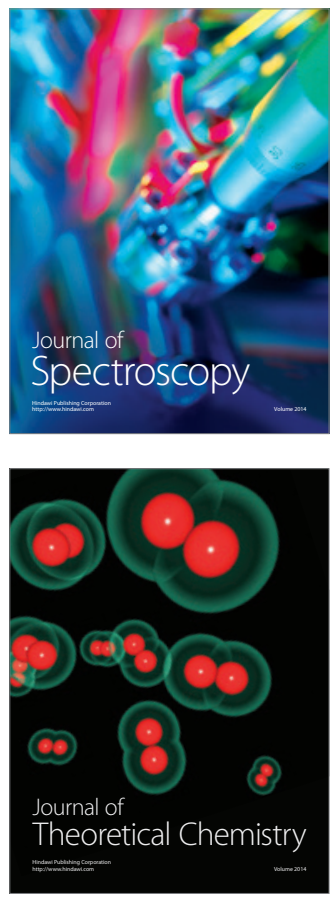
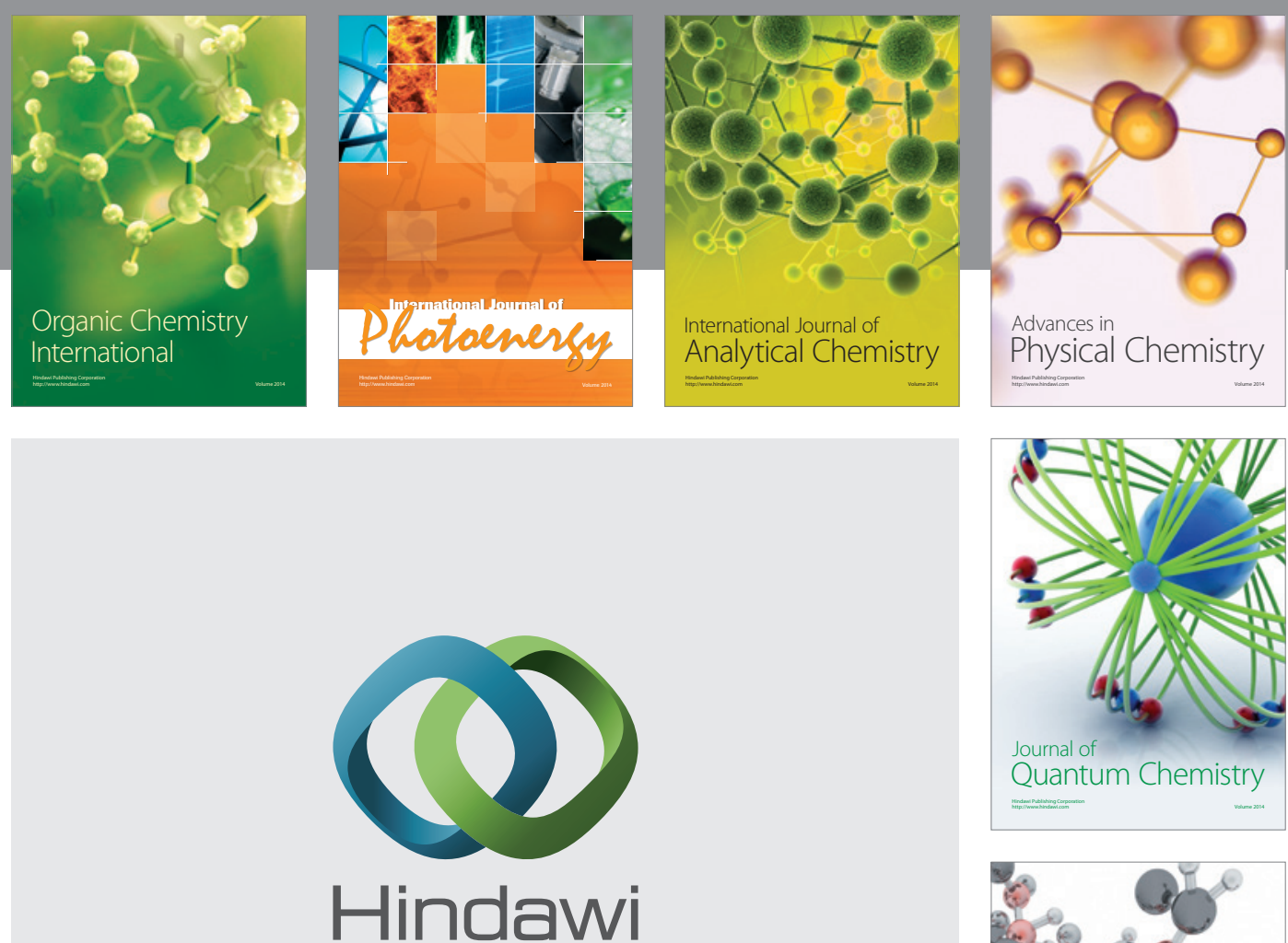

Submit your manuscripts at

http://www.hindawi.com

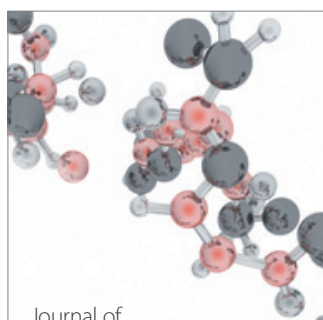

Analytical Methods

in Chemistry

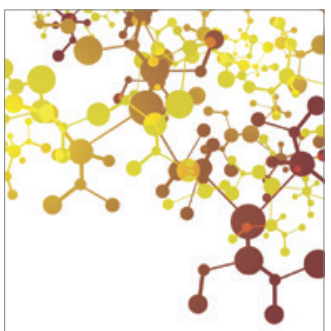

Journal of

Applied Chemistry

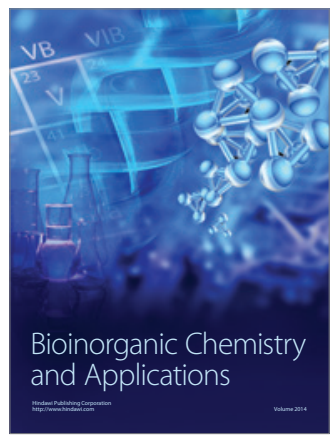

Inorganic Chemistry
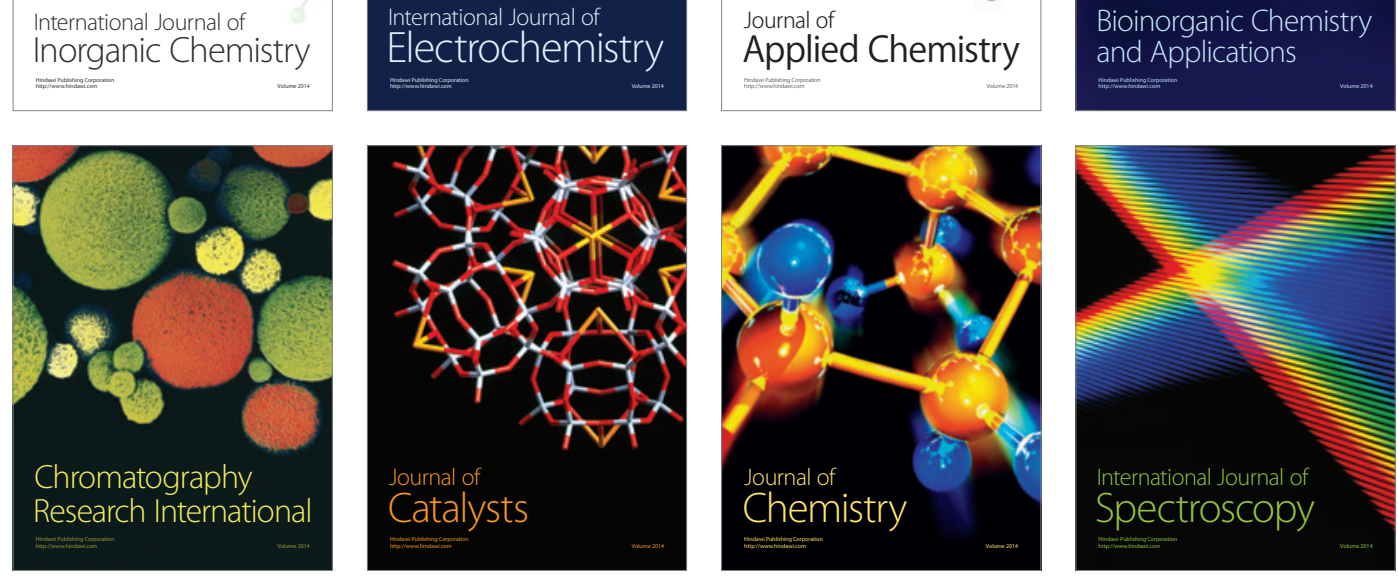